\title{
CURSOS SUPERIORES DE TECNOLOGIA: FUNDAMENTOS, CONTROVÉRSIAS \& DESAFIOS
}

\author{
CURSOS SUPERIORES DE TECNOLOGÍA: FUNDAMENTOS, CONTROVERSIAS Y \\ DESAFÍOS
}

\author{
HIGHER TECHNOLOGY COURSES: FOUNDATIONS, CONTROVERSIES AND \\ CHALLENGES
}

\author{
Mauro Lúcio Batista CAZAROTTI ${ }^{1}$ \\ Sueli Teresinha de Abreu BERNARDES ${ }^{2}$
}

RESUMO: Esta pesquisa tem como tema os Cursos Superiores de Tecnologia no Brasil. Desenvolvida na Linha de Pesquisa "Processos educacionais e seus fundamentos", vincula-se ao Núcleo de Estudos sobre o Professor, a Arte e a Filosofia - NEPAFi. A observação de que a formação acadêmica de nível superior no Brasil sempre foi destinada às elites, o aumento das demandas do mercado de trabalho e a influência do pensamento neoliberal. O recorte temporal para este estudo abrange os anos de 1969-2005, período que representa, respectivamente, o início da implantação dos CST no Brasil e o declínio da criação desses cursos no país. A pesquisa bibliográfica tem como aporte autores como Lima e Mioto (2007) e a análise documental fundamenta-se em Cellard (2008). Como resultados, constata-se que a proposta de cursos de tecnologia vigentes pode contribuir de modo significativo para que os indivíduos tenham uma formação efetiva em nível superior nessa área.

PALAVRAS-CHAVE: Cursos superiores de tecnologia. Educação profissional. Educação e trabalho. Fundamentos. controvérsias e desafios.

RESUMEN: Esta investigación tiene como tema los Cursos Superiores de Tecnología en Brasil. Desarrollada en la Línea de Investigación "Procesos educativos y sus fundamentos", se vincula al Núcleo de Estudios sobre el Profesor, el Arte y la Filosofía - NEPAFi. La observación de que la formación académica de nivel superior en Brasil siempre fue destinada a las élites, el aumento de las demandas del mercado de trabajo y la influencia del pensamiento neoliberal. El recorte temporal para este estudio abarca los años de 1969-2005, período que representa, respectivamente, el inicio de la implantación de los CST en Brasil y el declive de la creación de esos cursos en el país. La investigación bibliográfica tiene como aporte autores como Lima y Mioto (2007) y el análisis documental se fundamenta en Cellard (2008). Como resultados, se constata que la propuesta de cursos de tecnología vigentes puede contribuir de modo significativo para que los individuos tengan una formación efectiva a nivel superior en esa área.

${ }^{1}$ Universidade de Uberaba (UNIUBE), Uberaba - MG - Brasil. Pró-reitoria de Pesquisa, Pós-graduação e Extensão (PROPEPE). ORCID: <https://orcid.org/0000-0002-4386-4525>. E-mail: cazarotti@edu.uniube.br

${ }^{2}$ Universidade de Uberaba (UNIUBE), Uberaba - MG - Brasil. Doutora em Educação e Mestre em Educação Brasileira pela UFG. ORCID: <https://orcid.org/0000-0003-3731-521X>. E-mail: sueli.bernardes@uniube.br

RPGE- Revista on line de Política e Gestão Educacional, Araraquara, v. 22, n. 3, p. 992-1046, set./dez. 2018. E-ISSN:1519-9029. DOI: $10.22633 /$ rpge.v22i3.11368 
PALABRAS CLAVE: Cursos superiores de tecnología. Educación profesional. Educación y trabajo. Fundamentos, controversias y desafios.

ABSTRACT: This research has as its theme the Superior Courses of Technology in Brazil. Developed in the Research Line "Educational processes and their foundations", it is linked to the Nucleus of Studies on Teacher, Art and Philosophy - NEPAFi. The observation that higher education in Brazil has always been aimed at the elites, the increasing demands of the labor market and the influence of neoliberal thinking. The time cut for this study covers the years 1969-2005, which represents, respectively, the beginning of the implementation of TSA in Brazil and the decline in the creation of these courses in the country. The bibliographical research has as contribution authors like Lima and Mioto (2007) and the documentary analysis is based on Cellard (2008). As a result, it can be seen that the proposal of current technology courses can significantly contribute to individuals having an effective training at a higher level in this area.

KEYWORDS: Higher education technology; Professional education; Education and work; fundamentals, controversies and challenges.

\section{Introdução}

O ensino tecnológico foi introduzido na educação brasileira na década de 1960, no decorrer do regime militar, por intermédio da implantação do programa de desenvolvimento social e econômico "Aliança para o Progresso" e acordo "MEC-USAID”, frutos do convênio de cooperação firmado entre Brasil e Estados Unidos da América.

A evolução dos cursos de tecnologia no Brasil ${ }^{3}$ sempre foi marcada pelo interesse de grandes fomentadores. Desde a época de 1970, estes já incluíam os grandes bancos e investidores interessados na mão de obra especializada, que naquele momento estavam em busca de profissionais com formação superior e habilidades técnicas.

Para o Conselho de Dirigentes dos Centros Federais de Educação TecnológicaCONCEFET (2007), o desenvolvimento humano orientado para uma proposta de trabalho vinculada à realidade permite aos trabalhadores alimentarem expectativas melhores de vida.

\footnotetext{
3 Pensamos oportuno, de início, conceituar os níveis técnico e tecnológico: “a) O nível técnico, com uma organização curricular independente, destina-se a matriculados ou egressos do ensino médio. Aqui, situam-se a pressão e a direção para onde quer se encurralar o Sistema de Escolas Técnicas Federais. Trata-se de "flexibilizar seus currículos", adaptando-os às "competências" demandadas pelo mercado. Propõe-se um currículo modular, fundado na perspectiva das habilidades básicas e específicas de conhecimentos, atitudes e de gestão da qualidade, construtoras de competências polivalentes e, supostamente, geradoras da empregabilidade. Módulos que podem ser compostos em diferentes instituições públicas ou privadas. Subjacente a essa mudança, e em consonância com as diretrizes do Banco Mundial, situa-se a estratégia de transformar esse tipo de ensino num serviço a ser oferecido para o financiamento tanto do setor privado empresarial quanto do setor público. Vale dizer, um mecanismo claro de privatização. b) O nível tecnológico, destinado a egressos dos ensinos médio e técnico, para a formação de tecnólogos em nível superior em diferentes especialidades (FRIGOTTO, 1999, p. 11-12).
}

RPGE- Revista on line de Política e Gestão Educacional, Araraquara, v. 22, n. 3, p. 992-1046, set./dez. 2018. E-ISSN:1519-9029. 
Para esse Conselho, os Institutos Federais de Educação, Ciência e Tecnologia possuem identificação com as classes mais pobres e com a busca de emancipação; um caminho de redenção para aqueles que não conseguiram seguir o percurso acadêmico e retornam aos bancos escolares já adultos para resgatar o exercício de sua cidadania.

Segundo Araújo (2008), em 1996, ocorreram mudanças estruturais no ensino brasileiro introduzidas pela Lei de Diretrizes e Bases da Educação Nacional - LDB - regulamentandose a educação profissional, que passou a abranger os Cursos Superiores de Tecnologia (CST). Estes cursos de graduação e de menor duração (dois a três anos), se comparados ao bacharelado (quatro a cinco anos), formam tecnólogos qualificados especificamente para atender à demanda do mercado de trabalho.

O Catálogo Nacional de Cursos Superiores de Tecnologia, publicado pelo Ministério de Educação - MEC, em meados de 2006, e gestado, segundo seus autores, com a participação da comunidade educacional, é o documento-guia de oferta de cursos de graduação em tecnologia. Segundo o catálogo, esses cursos são organizados em treze eixos: ambiente e saúde, apoio escolar, controle e processos industriais, gestão e negócios, hospitalidade e lazer, informação e comunicação, infraestrutura, militar, produção alimentícia, produção cultural e design, produção industrial, recursos naturais e segurança (MEC, 2010).

Alguns autores trazem reflexões críticas a esses cursos superiores tecnológicos, tais como Santos e Jiménez (2009), Takahashi (2010), Juca et al. (2010), e Moacir Gadotti (2012). Nessa linha de análise, lemos em dois cientistas sociais:

Partimos do pressuposto de que, em última análise, tal modalidade de graduação [em Tecnologia] reproduziria, na esfera do ensino superior, o dualismo educacional que expressa historicamente o caráter de classe da escola capitalista, além de manifestar o rebaixamento de caráter imediatista e pragmático a que vem sendo submetido o ensino em geral, e o ensino superior em particular.

$[\ldots]$

É no plano do determinismo tecnológico que se manifesta o discurso dominante. Este declara, grosso modo, que a chamada Terceira Revolução Industrial veio colocar em questão os paradigmas educacionais até então vigentes, passando a exigir um outro modelo para a formação e composição de um novo perfil de trabalhador, que garantisse ao profissional a aquisição de múltiplas competências condizentes com as necessidades de um sistema produtivo agora regido pelo advento das tecnologias de base microeletrônica (SANTOS; JIMÉNEZ, 2009, p. 172).

Nesse cenário, esses autores elucidam que “[...] é fundamental salientar a atuação dos organismos internacionais que atuavam segundo os interesses do grande capital, constituindo um apoio de investimento na área social e, de modo especial, em educação profissional" 
(SANTOS; JIMÉNEZ, 2009, p. 173). Esses organismos representavam as políticas públicas de financiamento educacional, consubstanciadas a partir do Consenso de Washington, e são claramente conduzidos pelo Banco Mundial.

\begin{abstract}
Nesse instante histórico, a lucidez teórica de Florestan Fernandes já alertava para os perigos de se desenvolver um país perante a dependência financeira internacional, caminho comumente seguido na América Latina, principalmente nos países vitimados pelos golpes militares que proliferaram por este continente. Florestan Fernandes (1975) advertia que, caso esse caminho continuasse a ser trilhado, aprofundar-se-ia a distinção entre ensino e pesquisa, deixando o Brasil dependente tecnológica, política e culturalmente aos Estados de capitalismo central (SANTOS; JIMÉNEZ, 2009, p. 175).
\end{abstract}

Romanelli (1984 apud SANTOS; JIMÉNEZ, 2009, p. 175) assevera que esse desenvolvimento dependente "[...] não apenas assegura a expansão de mercados, mas também aumenta as distâncias entre os centros criadores de ciência e tecnologia e os países seus consumidores”, e, destacando sua posição, assevera, no mesmo parágrafo, que '[...] a modernização impede um desenvolvimento autônomo e transforma-se em mecanismo de dominação ou de controle do setor interno pelo externo" ROMANELLI (1984 apud SANTOS; JIMÉNEZ, 2009, p. 175).

Segundo Jucá, Oliveira e Souza (2010), a grande valorização dos Cursos Tecnológicos presentes nas divulgações e documentações das políticas educacionais para esse tipo de ensino deve ser vista com cautela. Isto porque os órgãos fomentadores e as grandes indústrias interessados nesse profissional, que é formado nos cursos tecnológicos, são os grandes interessados na mão de obra qualificada, emanada do ensino superior.

Com relação ao aspecto conceitual, as críticas que se fazem ao ensino de cursos superiores tecnológicos, de forma geral, continuam a fazer parte das preocupações dos teóricos contemporâneos. Nesse sentido, Gadotti (2012) reforça as preocupações quanto ao uso da educação tecnológica e profissional:

Concordamos que é preciso formar um trabalhador polivalente, capaz de adaptar-se no mundo do trabalho, capaz de cumprir múltiplas e diferentes funções, ser autônomo, em oposição à educação tecnicista, utilitarista e bancária. Entretanto, é preciso saber se formamos um trabalhador crítico ou completamente despolitizado como querem organismos internacionais como o Banco Mundial. É o que nos distingue dessas propostas. Também nos opomos à lógica das competências voltada apenas para o mercado de trabalho, fragmentando o conhecimento (GADOTTI, 2012, p. 3). 
Nesse contexto, ao longo do tempo, os cursos tecnológicos foram e estão sendo desenvolvidos cada vez mais para o mercado, fomentados pelos grandes financiadores mundiais. Partindo da importância dessa formação profissional, pensa-se como superar o dilema entre servir o mercado e atender ao desenvolvimento profissional que o trabalho tecnológico carece, tendo como pano de fundo a busca da compreensão e da crítica sobre a educação historicamente reservada à classe trabalhadora.

De reflexões como essas, foi construído o objeto desta pesquisa: os Cursos Superiores de Tecnologia. Todavia, como toda investigação, essa igualmente não se originou apenas de estudos bibliográficos.

Os descritores de pesquisa foram os seguintes: cursos superiores de tecnologia, educação profissional e educação e trabalho. Após a leitura inicial do resumo dos estudos que retornaram com a pesquisa dos descritores supracitados, foram realizadas a seleção dos mesmos e a leitura integral dos textos para a inclusão na revisão de literatura.

A partir do descritor "cursos superiores de tecnologia", identificamos, como resultado, várias produções acadêmicas. A primeira delas foi a dissertação "A formação inicial de professores de física em centros federais de educação tecnológica: contribuições e críticas", de Santos (2004). Nela, o autor afirma que o trabalho dos cursos superiores de tecnologia se fundamenta em questões políticas, como pode ser observado no contexto da formação de professores. Também é apresentado um contexto histórico sobre a criação dos centros de educação tecnológica em 1993.

Nesse mesmo ano, o Governo Federal criou o Sistema Nacional de Educação Tecnológica (SNET) e foi promulgada a Lei $n^{\circ}$ 9.394/96 - LDB -, que promoveu mudanças no cenário da educação brasileira e confirmou os princípios doutrinários caracterizadores da estrutura constitucional do Estado e os delineamentos ideológicos que se fundem com as políticas internacionais do país.

As primeiras experiências de Cursos Superiores de Tecnologia (engenharias de operação e cursos de formação de tecnólogos, ambos com três anos de duração) surgiram, no âmbito do Sistema Federal de Ensino e dos setores privado e público, em São Paulo, no final dos anos 1960 e início dos anos 1970. A autora não tem o objetivo de identificar a qualidade boa ou ruim - da proposta dos cursos superiores de tecnologia. Ela busca explicitar as novas contradições, descortinando características de um dos pilares da expansão do ensino superior brasileiro: a mão de obra especializada.

O interesse que se identifica na academia e nas políticas educacionais sobre os cursos tecnológicos, a observação de que a formação acadêmica de nível superior no Brasil sempre 
foi destinada às elites, o aumento das demandas do mercado de trabalho e a influência do pensamento neoliberal são aspectos que permeiam os trabalhos lidos. Igualmente, a oferta mais elevada de formação profissional, que implicou na implementação dos cursos superiores de tecnologia, entre as várias formações profissionalizantes no sistema educacional, também perpassa os textos analisados que fundamentaram e motivaram a escolha temática desta investigação.

Nesse sentido, durante as leituras e reflexões, surgiram algumas questões que embasaram o desenvolvimento desta pesquisa, a saber: como se fundamentam os Cursos Superiores Tecnológicos a partir da década de 1980? Quais as críticas e controvérsias referentes a esses cursos, identificadas em textos que compõem a literatura acadêmica e em documentos legais? Quais os desafios para esses cursos?

A partir dessas perguntas, estabelecemos como objetivo geral descrever e analisar os Cursos Superiores de Tecnologia (CST), destacando fundamentos, controvérsias e desafios em relação a esses cursos no Brasil. Os objetivos específicos remetem a: analisar documentos legais relacionados aos Cursos Superiores de Tecnologia; identificar fundamentos históricos, culturais, sociais, políticos e filosóficos para suas propostas; discutir os desafios sociais, culturais, científicos e pedagógicos para o desenvolvimento desses cursos.

O recorte temporal para este estudo abrange desde 1969, ano de implantação dos CST no Brasil, até 2005, data em que começa o declínio de criação de tais cursos. Desse período, selecionamos documentos legais que expressam as políticas públicas educacionais relativas aos cursos investigados.

Assumindo uma abordagem qualitativa, realizamos uma pesquisa descritiva, do tipo bibliográfica e documental, com enfoque qualitativo. A pesquisa bibliográfica teve como aporte autores como Lima e Mioto (2007), enquanto a análise documental pautou-se em Cellard (2008). No processo investigativo decorrente, envolvemos os seguintes procedimentos: mapeamento do estado do conhecimento e revisão da literatura; destaque de unidades significativas referentes a cada uma das perguntas de fundo de modo a evidenciar os aspectos relevantes do fenômeno estudado; preenchimento de quadros de análise dos dados e/ou informações contidos no material selecionado; leitura interpretativa, procurando relacionar as ideias expressas nos textos com o problema para o qual se buscou resposta; registro de contribuições dos textos para o estudo proposto, com reflexões, questionamentos e encaminhamentos suscitados pelas leituras, bem como na indicação de como poderiam ser utilizados na elaboração do texto final. 
Ao final, realizamos uma síntese integradora resultante da reflexão e das leituras realizadas, com aporte no ideário de Santos e Jiménez (2009), Takahashi (2010), Juca, Oliveira e Souza (2010) e Gadotti (2012), que discutem o tema desta dissertação. As meditações de Heidegger (1969) sobre a técnica foram, também, oportunas para embasarmos nossa atitude de pesquisador para o ato reflexivo da investigação realizada.

Consideramos a relevância deste estudo na necessidade de responder como a formação em Cursos Superiores de Tecnologia pode ser limitada, sendo considerada por alguns estudiosos como apenas uma formação especializada, e não como formação acadêmica de nível superior. Além disso, os resultados poderão contribuir para ampliar o debate sobre o tema, além de servir como fonte de consulta para leitores que se interessarem sobre as questões relacionadas aos Cursos Superiores de Tecnologia.

Ao mesmo tempo, sugerimos perspectivas e questões para novas investigações a serem efetivadas no sentido de fazer emergir propostas sobre aspectos dessa temática ainda não suficientemente desenvolvidos, de modo a conferir maior visibilidade ao assunto, bem como oferecer subsídios àqueles que pretendam aprofundar-se nessa natureza de estudo. Novas frentes de trabalho podem ser desenvolvidas, a partir dos resultados descritos e apresentados nesta dissertação.

\section{Educação Tecnológica: Reflexões sobre o conceito de técnica, a partir de meditações de Heidegger}

Martin Heidegger foi um filósofo, fundador da fenomenologia existencial, considerado um dos pensadores mais originais do século XX. Ele nasceu em 1889, em Messkirch (Alemanha), cursou estudos superiores em tecnologia e filosofia na Universidade de Friburgo, onde realizou seu doutorado em 1914 e onde foi aluno de Heinrich Rickert e Edmund Husserl, o fundador da fenomenologia. Seu falecimento, em Friburgo, data de 1976.

Em 1916, Heidegger iniciou sua carreira docente na própria Universidade de Friburgo e, posteriormente, passou à qualidade de professor titular de Filosofia naquela instituição. Faleceu em 26 de maio de 1976, na mesma cidade em que nasceu.

As raízes do pensamento de Heidegger estão profundamente arraigadas na tradição ocidental, ainda que o pensamento seja único em muitos dos seus aspectos, em sua linguagem e na sua expressão literária. Seu pensamento foi influenciado pelos gregos, pelo idealismo alemão, pela fenomenologia e pela tradição teológica escolástica. Estes e outros elementos 
foram fundidos por seu gênio de sensibilidade e do intelecto em uma expressão filosófica muito peculiar.

Para o filósofo de Messkirch, o pensamento genuíno é a maneira essencial de o homem ser ele mesmo. Rigorosamente existente e, mais raramente alcançado, o pensamento se manifesta na relação entre o homem e o Ser. Na verdade, Heidegger pode referir-se a pensar como uma arte. Como tal, o pensamento é fundamental para responder ao homem todas as questões. Informado pela lembrança, ele traz à consciência a eficácia do saber.

Assim, a reflexão de Heidegger sobre a natureza do pensar não está restrita a considerações sobre aquela forma de pensamento que se pretende estrita e propriamente filosófico. Ao contrário, ele evidencia a absoluta necessidade de adentrar certos âmbitos tidos como 'estranhos' ao pensar, tradicionalmente concebido tanto como representação quanto como querer.

\section{As relações entre formação humana, educação e trabalho}

O emprego do termo "globalização" começou a ser difundido no final dos anos 1980, inicialmente sugerindo a ideia de unificação global. Segundo Hobsbawn (1995), teria sido um movimento resultante de três processos que culminaram no final do século passado, a saber: a hegemonia da política neoliberalista, na figura de Margareth Thatcher - 1979 - e Ronald Reagan - 1980 -; a dificuldade da autonomia e formação de uma identidade dos países do Terceiro Mundo sob o peso dos empréstimos crescentes da dívida externa nas mãos de representantes do comando financeiro mundial como FMI e Banco Mundial; e a implosão da antiga União das Repúblicas Socialistas Soviéticas - URSS.

Segundo Ramos (2002, p. 1), quatro fatores contribuíram para conformar o processo de unificação no final do século passado: “[...] a globalização nas comunicações, a economia, a política e os valores presentes no convívio em todos os níveis: pessoal, social, nacional e mundial”. Podemos, ainda, inferir que a globalização se constituiu motor de mudanças na educação, a partir do fim do século XX, e contribuiu para o incremento à criação dos cursos tecnológicos.

O ideal progressista do início dos anos 1900 e a ânsia desenvolvimentista do pósguerra culminaram, a partir dos anos 1980, nas palavras de ordem da globalização: 1) competitividade empresarial; maior produtividade (avanço tecnológico e custo mínimo de mão de obra, auxiliado pela terceirização, matérias-primas e energia); e lucratividade 
(produtos de qualidade a preços acessíveis, com alto lucro ao menor custo). Isso demandava investimento em P\&D para atender ao mercado "mundializado".

Na década de 1980, na vigência do Welfare State ("Estado do bem-estar social"), criado nos EUA e países do Primeiro Mundo, inicia-se a política neoliberal nos EUA, na Inglaterra e em algumas nações latino-americanas. Essa política do neoliberalismo se vale da globalização para impor o câmbio livre, fazendo deslanchar o comércio internacional. O descrédito no comunismo foi um forte aliado dos teóricos neoliberalistas, sugerindo a crença na unificação da aldeia global de McLuhan - na verdade, a unificação dos mercados.

Também nos anos 1980, para Schrader (2002) citado por Santagada (2007), “[...] muitos países industrializados deslocaram o foco de atenção política do social para o econômico e para uma orientação conservadora [...]”, baseados numa orientação neoliberalista, aumentando a distância entre os países. Segundo Relatório do Desenvolvimento Humano do Programa das Nações Unidas para o Desenvolvimento (PNUD/ONU), havia três bilhões de pobres no planeta, enquanto aumentava a concentração de renda (SCHRADER, 2002, p. 18 apud SANTAGADA, 2007, p. 121).

Segundo Médici (2006), no Brasil, a Constituição Cidadã de 1988 privilegiava as políticas sociais. Porém, a inflação de três dígitos, a crise nas finanças públicas e os direitos constitucionais suprimidos pela ditadura configuravam conflitos a serem enfrentados pela nova ordem social e política.

No Brasil dos anos 1990, no governo de Itamar Franco e de seu sucessor Fernando Henrique Cardoso, é criado o Plano Real e, com isso, a estabilização da hiperinflação, que constituíram importantes feitos na área econômica. Segundo a orientação neoliberal, abriramse os mercados, com aumento das importações de bens, serviços e capitais, controle do dólar e altas taxas de juros, o que trouxe desarranjos de várias ordens para a economia.

Em 1999, o Brasil contava com uma força de trabalho de 79,3 (setenta e nove vírgula três) milhões de pessoas, segundo a Pesquisa Nacional por Amostra de Domicílio - PNAD -, sendo ampliada a presença feminina no mercado de trabalho. Comparativamente, em 1979, havia $31,7 \%$ (trinta e um vírgula sete) por cento de mulheres compondo a População Economicamente Ativa - PEA -, enquanto, em 1999, elas eram 41,4\% (quarenta e um vírgula quatro) por cento. "Tal situação aprofundou diversas mudanças de comportamento na sociedade como a maternidade adiada, o menor número de filhos, o aumento do padrão de consumo familiar e o investimento em educação" (OEI, 2010, p. 18). 
Segundo Saviani (2007), a sinergia entre trabalho e educação surge da relação de identidade: o homem aprendeu a garantir a subsistência no ato de produzi-la, ou seja, aprendeu a trabalhar trabalhando, transformando o meio ambiente e inter-relacionando-se.

Nas sociedades primitivas, o homem apropriava-se "[...] coletivamente dos meios de produção da existência e nesse processo educavam-se e educavam as novas gerações. Prevalecia, aí, o modo de produção comunal, também chamado de "comunismo primitivo". Não havia a divisão em classes. Tudo era feito em comum" (SAVIANI, 2007, p. 154). No processo de produzir a existência comum, educavam-se simultaneamente.

Na nascente civilização do Egito, já existia divisão entre ensino e trabalho. O ensino, tanto religioso como técnico, era restrito a poucos, como os sacerdotes, que submetiam os alunos a práticas de iniciação. Na Mesopotâmia, o ensino era familiar, repassado de geração em geração, de pais para filhos, transmitindo, assim, os saberes. De início, predominava a educação doméstica, em que os saberes, crenças e habilidades eram transmitidos de pai para filho. Após 1240 a.C., quando os assírios conquistaram a Babilônia, foram criadas escolas públicas.

Para Platão, a educação deveria ser repassada conforme as necessidades e diferenças do meio social que, para ele, existiam entre as pessoas, para que cada indivíduo pudesse ocupar seus cargos na sociedade, o que acontecia por seguidas seleções.

Saviani (2007) explica que o processo de produção, ao longo dos anos, possibilitou separar o ensino da produção. Essa separação espelhou o afastamento da manufatura e do trabalho intelectual. Mas, após a divisão, observa-se que a relação trabalho-ensino assume uma dupla identidade:

De um lado, continuamos a ter, no caso do trabalho manual, uma educação que se realizava concomitantemente ao próprio processo de trabalho. De outro lado, passamos a ter a educação de tipo escolar destinada à educação para o trabalho intelectual (SAVIANI, 2007, p. 157).

Com a Revolução Industrial, a indústria passa a dominar a produção, materializam-se as funções intelectuais no processo produtivo e a escola passa a dar a orientação intelectual para a sociedade, generalizando a escola básica. "Portanto, à Revolução Industrial correspondeu uma Revolução Educacional: aquela colocou a máquina no centro do processo produtivo; esta erigiu a escola em forma principal e dominante de educação" (SAVIANI, 2007, p. 157).

$\mathrm{Na}$ produção, o capitalista apropria-se do saber historicamente acumulado pelo trabalhador, "[...] de suas ferramentas de trabalho e da decisão sobre o que, como, quando e 
para que produzir" (FELIZARDO, 2010, p. 5). O trabalhador torna-se uma etapa da produção. A evolução tecnológica permitiu controlar o processo produtivo e aumentar a produtividade. Por sua vez, o capital tratou de educar e orientar a mão de obra, garantindo a posse do saber do trabalhador.

O capitalismo, em busca de aumento de produtividade, converge-se para o desenvolvimento da tecnologia industrial (século XVIII), o que permite romper as fronteiras entre as nações, em busca de mercados e mão de obra mais atrativos. Assim, para que possa inserir-se no mercado de trabalho, o trabalhador precisa dominar qualificações cada vez mais complexas e variadas, além de ter de saber usar tecnologias indispensáveis da vida moderna, como a informática (FELIZARDO, 2010).

Em busca de sobrevivência, o homem viu-se obrigado a transformar o ambiente natural e a si mesmo. Como diz Saviani (2007), o homem, a fim de garantir a subsistência, aprendeu a trabalhar trabalhando e transformando o meio ambiente, relacionando-se com seus pares, educando-se e educando a geração seguinte, até que, com a sociedade de classes (escravista/feudal) separaram-se educação e trabalho, a manufatura do trabalho intelectual. No entanto, na manufatura, permanecia a necessidade de educar-se o trabalhador no próprio processo de trabalho. Essa é a natureza do ensino técnico que, com variações, perdura até hoje, com a globalização. O capital força o desenvolvimento da tecnologia industrial, o que passa a exigir um trabalhador qualificado.

No Brasil, desde a criação de liceus de artes e ofícios, em São Paulo e no Rio de Janeiro, buscava-se disseminar, entre os operários, a instrução artística e técnica, das artes e dos ofícios industriais. Na época contemporânea, o panorama do ensino profissionalizante é complexo, dividindo-se em: 1) educação inicial, que busca qualificar quem procura emprego ou requalificar quem está empregado, por meio de cursos rápidos oferecidos por Organizações Não Governamentais, instituições públicas, associações, sindicatos; 2) formação tecnológica, visando à profissionalização de nível superior; 3) formação técnica, destinada a formandos do Ensino Fundamental que desejam a profissionalização no Nível Médio.

Esse contexto está conformado, hoje, por uma série de leis, decretos e resoluções que têm sido colocados em prática pelas três instâncias de governo e pela iniciativa privada ou organizações classistas e sem fins lucrativos. Isso permitiu que, entre os anos de 2001 e 2010, o total de matrículas na educação técnica profissional de Nível Médio crescesse 129,7\% (cento e vinte e nove vírgula sete) por cento, no Brasil, conforme o "Relatório Educação para 
Todos no Brasil 2000-2015”. Só o Pronatec cresceu 278,1\% (duzentos e setenta e oito vírgula um) por cento, em três anos (2011-2014), com mais de sete milhões de alunos ${ }^{4}$.

Além das bem-sucedidas políticas de inclusão e diversidade de então, a meta que avizinha é a universalização, sendo o foco da política educacional equilibrar metas quantitativas e qualitativas a fim de reduzir as desigualdades.

No ano de 2015, em visita ao presidente Barack Obama, a ex-presidente Dilma Rousseff aproveitou para discutir a experiência americana de ensino profissionalizante com as community colleges, ou seja, com as faculdades que oferecem, naquele país, cursos superiores de dois anos de duração que dão diploma de técnico ou servem como períodos iniciais para completar a formação em uma universidade, já observando fatores da globalização que estão interferindo no processo educacional.

A solução para encontrar a imprescindível mão de obra qualificada passa a ser amplamente divulgada: a filosofia educacional tecnicista. Baseada na tendência liberal tecnicista, prega o aprimoramento da sociedade capitalista, articulando a educação com o sistema produtivo. Para tanto, busca-se valer de métodos científicos para propor adaptação de comportamento (tecnologia comportamental) cujo objetivo primordial é fornecer trabalhadores “[...] competentes para o mercado de trabalho, não se preocupando com as mudanças sociais" (MARQUES, 2012, p. 4).

A educação tecnológica efetivada nos cursos tecnológicos tem como finalidade precípua solucionar duas demandas crescentes e imperativas em termos de globalização: levar formação profissionalizante às massas populares - demanda social reprimida que exige solução rápida e eficaz - e preencher as vagas da indústria financiada pelo capital neoliberal que, açodada pela intensa competição, investe maciçamente em tecnologia e cria cargos que precisam ser preenchidos por mão de obra qualificada.

Além de ser impossível para a sociedade e mesmo uma irresponsabilidade dos governos negligenciarem a educação tecnológica, trata-se de uma solução bem-vinda. Alçados, no Brasil, ao status de graduação, os Cursos Superiores de Tecnologia formam profissionais em áreas em que não há outras graduações. São indicados para pessoas que precisam ser inseridas com brevidade no mercado de trabalho, especialmente em função de duração mais curta que o bacharelado.

4 Oliveira e Carneiro (2012, p. 16) elucidam que "[...] no governo Lula houve um fortalecimento da Rede Federal de Educação, com ampliação da oferta de vagas, qualificação permanente dos servidores técnicos, administrativos e docentes, além da qualidade e investimento no ensino, pesquisa e extensão. Todas essas iniciativas contribuíram de forma positiva para a superação do modelo neoliberal na educação profissional". Atualmente, vivemos um momento oposto quanto à expansão de vagas, em decorrência da ideologia partidária que ocupa o poder. 
O maior desafio da educação profissional está em atender às necessidades e às exigências de empresas que estão, cada vez mais, buscando ampliar sua qualidade em relação ao conhecimento e ao capital intelectual, o que muitas vezes não é acompanhado pela educação profissional.

Considerando as constantes mudanças que rondam as exigências do mercado de trabalho e o crescimento do ensino superior no Brasil, analisa-se a importância em assegurar a valorização da diversidade na era rápida da informação, visto que as transformações sociais, políticas, econômicas e culturais aumentam a cada dia (SILVA, 2008).

É notório que essas transformações conseguem influenciar a demanda educacional. Antigamente, as mudanças na sociedade demoravam um longo tempo para ocorrer. Nos dias de hoje, as mesmas ocorrem de maneira mais rápida e gradativa. Assim:
À universidade resta o compromisso de gerar o saber, o qual está interligado à verdade, justiça e igualdade. Entretanto a quantidade de ofertas no ensino superior não reflete, necessariamente, qualidade. Observa-se que os formandos deixam suas cadeiras e partem rumo à vida profissional, carentes de o verdadeiro saber. Tal fato se deve ao distanciamento entre o conteúdo das disciplinas - constante nos currículos - e a velocidade das transformações nos variados campos do conhecimento científico e tecnológico. O ingresso ao mercado de trabalho torna-se extremamente penoso à medida que o profissional carece de uma boa formação universitária (SILVA, 2008, p. 48).

Nesse sentido, o aumento da qualificação dos profissionais docentes, juntamente com o desenvolvimento de novas metodologias pedagógicas, faz-se totalmente necessário, devendo estar ambas voltadas para a interação entre alunos e professores, contribuindo para a humanização do ensino superior.

Com isso, as transformações econômicas são responsáveis por influenciar as regras e padrões praticados pelo ensino. Os aspectos atuais da educação envolvem tendências relacionadas ao crescimento futuro dessa área, refletindo, significativamente, na promoção do desenvolvimento social e cultural, transformando as instituições de ensino superior em organizações incentivadoras do conhecimento.

Atualmente, o ensino superior, no Brasil, mantém ainda posturas associadas aos modelos mais antigos de educação, estabelecidas pelos modelos europeus; porém, estes modelos sofreram mudanças significativas, em que as propostas pedagógicas se tornaram mais exigentes e complexas, visando ao aumento da qualidade do ensino superior no país (PIMENTA; ANASTASIOU, 2002).

É por meio da valorização dos aspectos econômicos que ocorre a comercialização do ensino, predominando a busca por ações que visem ao crescimento do ensino superior por 
meio de critérios utilitaristas. Nessa direção, a educação passará a apresentar o objetivo de atender aos interesses de determinada parcela da sociedade. Assim, o ambiente de educação superior não possui apenas a missão de educar o cidadão, mas também de contribuir com o desenvolvimento econômico do país.

Em relação ao papel público no desenvolvimento do ensino superior, Schwartzman (2007) considera que as políticas públicas não devem se preocupar apenas com o financiamento e com as regulamentações de todo o sistema educacional superior. Cabe ao governo, também, desenvolver estratégias e ações que visem à estimulação da pesquisa, ao aumento da qualidade do ensino, à valorização da diversificação regional. Através destes objetivos é possível estimular o desenvolvimento de outras áreas estratégicas, promovendo a equidade e proporcionando a toda a população brasileira melhores condições de infraestrutura, assegurando normas consistentes para que a educação superior possa ser efetivada.

Observa-se que a educação superior possui uma organização social, cujo objetivo é disponibilizar oportunidades de crescimento intelectual e científico para toda a população, cabendo à mesma adotar uma postura de acordo com normas e valores determinados pela sociedade na qual se insere. Dessa maneira, é caracterizada pelo importante papel estável e durável em sua comunidade. De modo geral, as Instituições de Ensino Superior devem estar baseadas em um ideal integrador entre a qualificação dos alunos e o incentivo ao desenvolvimento da nação.

\section{Concepções de educação tecnológica}

Ao falar em tecnologia, vêm à mente sofisticados artigos de consumo como celulares, produtos de informática etc. Todavia, tecnologia é muito mais que isso, algo que existe desde que o homem visualizou que poderia modificar e dar a uma pedra, um osso, um galho de árvore uma nova utilização, dando o passo inicial para conquistar o futuro.

Há inúmeras conceituações e contextualizações para tecnologia. Segundo Veraszto (2008), a estreita visão que considera a tecnologia como algo independente de sistema político ou social “[...] impede a análise crítica e ignora as intenções e interesses sociais, econômicos e políticos daqueles que a idealizam, financiam e controlam” (VERASZTO, 2008, p. 70). A tecnologia não é neutra, pois representa propósitos e valores da sociedade.

A tecnologia configura e condiciona o modo de vida moderno: 
Sem dúvida, o desenvolvimento tecnológico terá um impacto social, poderá alterar nossos padrões de vida e convivência chegando a gerar outros totalmente distintos, mas esse desenvolvimento é sustentado por uma série de interesses e valores externos e não age por lógica própria" (GARCÍA et al, 2000 apud VERASZTO, 2008, p. 71).

Um dos efeitos dúbios das novas Tecnologias da Informação e da Comunicação - TIC - diz respeito ao fato de se socializarem saberes e mesmo serem padronizados os significados dados às coisas do mundo, à vida, à sociedade, ao ambiente.

Para Zart et al (1998), nada supera a tecnologia como ferramenta de dominação e de controle sobre a natureza e sobre a sociedade, visto que o avanço da tecnologia se transforma em estratégia do desenvolvimento capitalista. Isto acontece, especialmente, pelo fato de a ciência desenvolvimentista e os meios de produção pertencerem ao empresariado, sem estar, obrigatoriamente, direcionadas para atender às necessidades básicas das pessoas. O uso das TIC apenas funciona como estratégia da ideologia dominante que transmite a crença de que, assim, constitui-se a via para o bem-estar de toda a sociedade.

Winner (1987, apud COLOMBO; BAZZO, 1998) faz apologia do controle da tecnologia e propõe a Filosofia da Tecnologia”, cuja missão é escrutinar, criticamente, a natureza e o significado das inovações tecnológicas para a vida humana. Ou seja, significa o como fazer para monitorar a produção de tecnologia a fim de adequá-la ao senso de quem somos e em que espécie de mundo desejamos viver.

Uma das referências que a legislação brasileira atual faz à educação tecnológica consta do art. $3^{\circ}$ da Resolução CNE/CEB n. ${ }^{\circ} 1$, de 3 de fevereiro de 2005 :

Art. $3^{\circ}$ A nomenclatura dos cursos e programas de Educação Profissional passará a ser atualizada nos seguintes termos:

I. 'Educação Profissional de nível básico' passa a denominar-se 'formação inicial e continuada de trabalhadores';

II. 'Educação Profissional de nível técnico' passa a denominar-se 'Educação Profissional Técnica de nível médio';

III. 'Educação Profissional de nível tecnológico' passa a denominar-se 'Educação Profissional Tecnológica, de graduação e de pós-graduação' (CNE/CEB, 2005, p. 01).

Nunes Durães (2009) comenta que este artigo reafirma o uso dos termos constantes no Decreto $\mathrm{n}^{\circ} 5.154 / 04$, o qual especifica, no art. $1^{\circ}$, os níveis de ensino dos programas de Educação Profissional. A legislação não emprega as expressões Educação Técnica e Educação Tecnológica propriamente ditas, mas usa uma expressão próxima, Educação Profissional Técnica e Educação Profissional Tecnológica, para definir os níveis de ensino da 
Educação Profissional. Nesse caso, a Educação Técnica refere-se ao nível médio de ensino da Educação Profissional e a Educação Tecnológica corresponde ao nível superior, de graduação e de pós-graduação, desse tipo de educação.

É possível identificar a utilização de sentidos diferentes desse significado legal acima apresentado. Para tal autora, o uso das expressões não é relativo ao nível de ensino.

Ou seja, pode-se utilizar educação técnica e educação tecnológica tanto na formação inicial, quanto no nível médio e na graduação da Educação Profissional, assim como no Ensino Propedêutico. As concepções, nesse caso, referem-se às orientações político-pedagógicas subjacentes aos modelos de formação (NUNES DURÃES, 2009, p. 164).

Nas discussões conceituais contemporâneas, Oliveira (2000) relaciona o conceito de formação técnica ao "saber fazer", observando que as "[...] diferenças entre formação técnica e formação tecnológica têm sido objeto de intenso e extenso debate nas Instituições de Educação Tecnológica no País" (OLIVEIRA, 2000, p. 41). A autora aproxima o conceito de formação técnica "[...] aos processos de treinamento do trabalhador no mero domínio das técnicas de execução de atividades e tarefas, no setor produtivo e de serviços" (OLIVEIRA, 2000, p. 41). Enquanto formação tecnológica envolveria, entre outros, “[...] o compromisso do trabalhador para dominar processos físicos e organizacionais ligados aos arranjos materiais e sociais, e de conhecimento aplicado e aplicável; princípios científicos e tecnológicos específicos de um determinado ramo de atividade humana" (OLIVEIRA, 2000, p. 41-42).

Essa autora ainda relaciona formação tecnológica a uma educação extensa, que abarque uma formação intelectual, cultural, científica e técnica, unida a uma compreensão histórica do desenvolvimento tecnológico e societário.

Grinspun (2001) igualmente discorre sobre a relação necessária entre tecnologia e educação ao falar de educação tecnológica. Sobre o significado do termo, a autora reflete que:

Na dimensão educação tecnológica vou buscar o significado desta expressão [educação tecnológica] à luz de uma filosofia que oriente a educação do sujeito para que ele seja capaz tanto de criar a tecnologia, como desfrutar dela e refletir sobre a sua influência na sua própria formação e de toda a sociedade. [...] $\mathrm{O}$ conceito de educação tecnológica diz respeito [...] à formação do indivíduo para viver na era tecnológica, de uma forma mais crítica e mais humana, ou à aquisição de conhecimentos necessários à formação profissional (tanto uma formação geral como específica), assim como às questões mais contextuais da tecnologia, envolvendo tanto a invenção como a inovação tecnológica (GRISNPUN, 2001, p. 27-28). 
Salientamos que as autoras Nunes Durães (2009), Oliveira (2000) e Grisnpun (2001) não analisam a educação tecnológica como uma formação já existente nas instituições de ensino, mas sim, como um modelo formativo necessário para a transformação da nossa atual sociedade, em busca de mais justiça e humanismo.

Do mesmo modo, valorizando uma formação integral dos cidadãos, Barros (1997) elucida que:

[...] a educação tecnológica está baseada numa concepção ampla e universal de educação, que transcende os conceitos fragmentados, pontuais ou direcionados do ensino, aprendizado e formação, substituindo-os pela integração renovada do saber, do fazer, do saber fazer e do pensar e repensar no saber e no fazer, como objetos permanentes da ação e reflexão crítica sobre a ação. Abrangendo, várias modalidades de formação e capacitação, a educação tecnológica não se caracteriza pela divisão de níveis e graus de ensino, mas pelo caráter global e unificado da formação técnico-profissional, integrada aos pressupostos mais amplos da conscientização do trabalhador e da construção de cidadania, dirigida especificamente para a produção social (BARROS, 1997, p. 15).

É possível confirmar, com as palavras de Barros (1997), que a compreensão epistemológica do termo "educação tecnológica" não se relaciona a nenhum nível específico de formação, mas se reporta a uma formação ampla, voltada à formação do trabalhador cidadão.

Nessa linha de pensamento, vemos igualmente Coelho (1997) afirmar:

O conceito de educação tecnológica possui uma abrangência maior, implicando uma formação que prevê o desenvolvimento integral do trabalhador, de suas amplas habilidades cognitivas - que incluem, mas ultrapassam a assimilação de informações técnicas, enfatizando o domínio dos fundamentos científicos subjacentes ao saber fazer -, de suas habilidades sócio-afetivas, de sua ética e de uma reflexão sobre valores que incluam o estudo crítico do contexto sócio-político e econômico em que a ciência e a tecnologia são produzidas, disseminadas e aplicadas (ou não) (COELHO, 1997, p. 52).

Assim, essa educação relaciona-se à possibilidade de uma formação mais ampla, que inclui e ultrapassa a educação técnica, possibilitando uma formação crítica que desenvolva aspectos pertinentes à cognição, à literatura, à arte, à cultura popular e à criatividade dos alunos.

Entretanto, alguns autores divergem dessas concepções. Pair (2002), por exemplo, afirma que prefere "[...] chamar de tecnológica uma formação acadêmica construída em torno 
de disciplinas tecnológicas, por exemplo, a mecânica ou a eletricidade, e não orientada para uma profissão, por exemplo, as de torneiro ou de eletricista" (PAIR, 2002, p. 13).

Em Portugal, Reis (1995) pondera que a finalidade da educação tecnológica “[...] não está em ensinar a usar a mais moderna peça de hardware, mas em perguntar quando e por quê ela deve ser usada" (REIS, 1995, p. 49). Segundo esse autor, é necessário que o aluno seja preparado para lidar com a tecnologia, mas que, igualmente, aprenda a questionar e a tomar decisões no mundo do trabalho e na sociedade em que vivemos.

A partir das concepções consultadas, podemos pensar que a educação tecnológica supõe uma formação ampla, que atente para a formação profissional com consistente fundamento científico, com capacidade de construir, aplicar e gerir tecnologias, e que, sobretudo, preocupe-se com a formação do trabalhador-cidadão que saiba questionar e posicionar-se no seu contexto social. E pensamos como Gadotti (2012), para quem cidadania é essencialmente consciência de direitos, de deveres e exercício da democracia.

Continuando nossas reflexões, no próximo capítulo discorremos sobre os CSTs em nosso país.

\section{Cursos Superiores de Tecnologia no Brasil}

No Brasil, após o descobrimento, demorou meio século até que aqui viessem os primeiros jesuítas, responsáveis pela instalação das escolas, iniciando a aculturação europeia dos indígenas - educação das crianças, trabalho, crença nas divindades, modo de relacionar-se com a natureza, tudo deveria ser substituído pela cultura do colonizador. Porém, desde cedo, a atenção era dada à "[...] educação escolar das crianças e jovens mais ricos. Aos índios, pobres e negros era dada a catequese oral e, em pouquíssimos casos, ensinavam-se a leitura e a escrita" (LOPES et al, 2005, p. 13).

A formação do trabalhador no Brasil começou a ser feita desde os tempos mais remotos da colonização, tendo como os primeiros aprendizes de ofícios os índios e os escravos, e "habituou-se o povo de nossa terra a ver aquela forma de ensino como destinada somente a elementos das mais baixas categorias sociais" (FONSECA, 1961, p. 68).

Entre descobertas, avanços e retrocessos, no ano de 1785, o desenvolvimento tecnológico do Brasil ficou estagnado, com a proibição da existência de fábricas, obviamente devido ao medo de que este viesse a se libertar das ataduras com Portugal, por ser o Brasil um país com abundância de recursos naturais, o que, aliado à indústria, se tornaria um perigo para as metrópoles. De acordo com Garcia (2000), em 1808, D. João VI revoga a então 
estabelecida proibição e cria o Colégio das Fábricas, considerado o primeiro estabelecimento instalado pelo poder público. Contudo, o objetivo deste era atender a educação dos artistas e aprendizes portugueses, Anos mais tarde, o então presidente do Estado do Rio de Janeiro, Nilo Peçanha, iniciou no Brasil o ensino técnico por meio do Decreto $\mathrm{n}^{\circ} 787$, de 11 de setembro de 1906, criando quatro escolas profissionais naquela unidade federativa, para o ensino de ofícios e aprendizagem agrícola.

Com a onda iluminista que varria a Europa, as reformas do ensino em Portugal ficaram a cargo de Marquês de Pombal. Valorizava-se o conhecimento como formas de submeter a natureza e os outros homens. Em 1759, Pombal expulsa os jesuítas do Brasil e os responsabiliza pelo atraso no ensino, criando as escolas régias, que ofereciam ensino público e alcançaram o século XIX ao lado de escolas mantidas pelas famílias. Era a época da Independência do Brasil, quando passa a haver a preocupação com a educação das classes inferiores da sociedade. A Constituição assinada por Dom Pedro I, em 1824, determinava educação básica gratuita para todos. Torna-se foco de debate o ensino como responsabilidade do Estado (LOPES et al, 2005, p. 13).

Próximo ao início do período republicano, com o descrédito na monarquia e a esperança de um regime democrático, como na França e nos EUA, em que o povo participava das decisões, reforça-se a ideia de oferecer escolas para todas as crianças. Surge o chamado método intuitivo (que pregava que as crianças aprendiam por si, pela intuição) e os primeiros jardins de infância. Entre as melhorias introduzidas, os médicos “[...] defendiam que as escolas não podiam mais funcionar sem cadeiras, com as crianças sentadas no chão ou em cima de caixotes sem encosto e em ambientes insalubres, sem luz e ventilação" (LOPES et al, 2005, p. 21).

Após a morte de Afonso Pena, em 1909, Nilo Peçanha assume a Presidência do Brasil e assina o Decreto $\mathrm{n}^{\mathrm{o}}$ 7.566, criando inicialmente dezenove Escolas de Aprendizes Artífices em todo o território, as quais eram subordinadas ao Ministério da Agricultura, Indústria e Comércio, marcando oficialmente a implementação do ensino técnico, primário e gratuito.

A virada do século trouxe a inauguração dos grupos escolares, e o magistério estava praticamente a cargo da força feminina. Os problemas assomavam: nas décadas inicias do século XX, a escolarização das crianças brasileiras era das piores do mundo: "Em Minas Gerais, um dos principais estados da federação, apenas $10 \%$ das crianças em idade escolar estava frequentando (sic) a escola em 1910!” (LOPES et al, 2005, p. 23). Passa-se a falar em reforma do ensino.

No Brasil, o movimento escolanovista ganha força a partir de 1930, sendo um marco o 
"Manifesto dos Pioneiros da Escola Nova", de 19325. Designado como Educação Nova, tem raízes na produção científica e pedagógica do fim do século XIX, especialmente a partir da emancipação de ciências como a Psicologia e a Sociologia. Esse movimento surgiu na Europa ocidental, América do Norte e do Sul na virada do século XIX para XX: "Seu pensamento exprime-se sobretudo por 'Práticas Pedagógicas Inovadoras' e, paralelamente, com um corte radical com o passado" (ALVES, 2012, p. 71). A Escola Nova como divisor de águas foi estudada nas análises do passado educacional brasileiro, em trabalhos de importantes educadores, como Fernando de Azevedo, com a obra "A cultura brasileira" (VIDAL; FARIA FILHO, 2003).

Na década de 1930, com a primeira subida de Getúlio Vargas ao poder e depois com o Estado Novo (1937-1945), a educação passa a funcionar como instrumento de publicidade para o governo, sendo as vozes democráticas então caladas. O fim da Segunda Guerra e a queda de Getúlio fazem ressurgir as esperanças, com críticas aos rumos que a educação tomara e em "[...] defesa da expansão da escola primária e secundária para toda a população" (LOPES et al, 2005, p. 25). Contra a escola excludente e elitista, professores e intelectuais passam a defender um sistema nacional de educação. É fundado, em 1938, o Instituto Nacional de Estudos Pedagógicos (Inep), do Ministério da Educação e Saúde (VIDAL; FARIA FILHO, 2003).

A partir de 1941, o ensino profissional passou a ser considerado de nível médio e, com o Decreto n ${ }^{\circ} 4.127$, de 1942, as Escolas de Aprendizes e Artífices se transformam em Escolas Industriais e Técnicas, passando a oferecer a formação profissional em nível equivalente ao do secundário. A partir desse ano, inicia-se, formalmente, o processo de vinculação do ensino industrial à estrutura do ensino do país como um todo, uma vez que os alunos formados nos cursos técnicos ficavam autorizados a ingressar no ensino superior em área equivalente à da sua formação (BRASIL, 2011).

A Constituição de 1946 determina a criação de uma Lei de Diretrizes e Bases da Educação Nacional (LDBEN), que só seria promulgada em 20 de dezembro de 1961: a Lei nº 4.024. Na virada da década de 1950 para 1960, em Angicos (RN), uma equipe de educadores propôs uma experiência de ensino inovadora que fundamentaria a educação popular e, sob comando de Paulo Freire, inicia-se um projeto de alfabetização de adultos que ganharia repercussão nacional e internacional - o método Paulo Freire de Alfabetização de Adultos (LOPES et al, 2005).

5 O leitor interessado poderá ler, na íntegra, "O manifesto dos pioneiros da educação nova (1932): a reconstrução educacional no Brasil - ao povo e ao governo", Revista História da Educação Brasileira (2006). 
Kuenzer (1997) salienta que era bem demarcada a trajetória educacional daqueles que iriam desempenhar funções intelectuais ou instrumentais numa sociedade que delimitava a divisão social e técnica do trabalho.

No ano de 1959, as Escolas Industriais e Técnicas são transformadas em Escolas Técnicas Federais. Estas ganham autonomia didática e de gestão. Com isso, intensifica-se a formação de técnicos, mão de obra indispensável diante da aceleração do processo de industrialização, buscando atender às necessidades do setor produtivo. Em nome do desenvolvimento econômico da nação, a educação superior implantou os Cursos Superiores de Tecnologia-CST.

A educação profissional tecnológica, em se tratando de cursos de curta duração de ensino superior, pode-se citar que seu início se deu por volta do ano de 1963, com a criação dos cursos de curta duração para formação de engenharia de operações, com duração curta de três anos.

No início da década de 1960, se fortalece:

[...] todo um debate acerca da necessidade de se reformular nosso sistema universitário, considerando-se, dentre outros, dois problemas centrais: primeiro, apesar da expansão do ensino superior no período republicano, a pressão, por parte dos jovens, quanto ao acesso aos níveis superiores de educação tornava-se cada vez maior; segundo, a constatação de que nosso sistema universitário estava desvinculado da realidade nacional, não sendo capaz de formar os jovens para enfrentar o processo de desenvolvimento urbano e industrial que ocorria (BRANDÃO, 2009, p.3).

De lá para cá, se passaram por grandes transformações e aceitação, sendo ainda uma modalidade que está, na atualidade, em expansão no Brasil.

De acordo com Brandão (2009), "uma das características específicas destes cursos seria o fato de serem organizados com base em uma duração mais curta e, portanto, em uma perspectiva distinta", perfazendo uma modalidade que pudesse orientar o público que buscava um ensino superior e também, ao mesmo tempo, acoplar estes profissionais de acordo com a demanda momentânea que estava tendo no mercado.

Sua criação foi autorizada pela Diretoria do Ensino Superior, o que viria posteriormente a ser o Departamento de Assuntos Universitários - DAU, do Ministério da Educação e Cultura (MEC). O que foi encaminhado e aprovado a uma nova modalidade de ensino, mesmo não sendo a usual e que era fortemente caracterizada como engenharia, mas uma nova formação em um curto tempo de espaço (BRANDÃO, 2009). 
Para atender demandas da indústria, em especial da automobilística que, em função do crescente desenvolvimento tecnológico, passou a exigir um profissional mais especializado em uma faixa menor de atividades, capaz de encaminhar soluções para os problemas práticos do dia a dia da produção (BRASIL, 2002, p. 13).

É nítido, desde os primórdios da criação dos cursos de curta duração, seu fomento como critério utilizado para atender demandas da sociedade, sendo o viés de direcionamento o mercado de trabalho.

Em fevereiro de 1963, é aprovada a criação dos cursos de curta duração, sendo que, em 1965, é aprovado um parecer em definitivo sobre os cursos de curta duração. Esta nova modalidade fica conhecida como um curso de curta duração, ou como já se chamavam, cursos de "formação profissional tecnológica". Deixa-se ainda mais explícito que o engenheiro de operação, como a própria nomenclatura escolhida mostra, é um profissional com formação voltada para a prática (BRANDÃO, 2009).

Os que pensavam que o ensino tecnológico, ou o futuro progressista de desenvolvimento, se desenvolveu com os militares advindos do golpe militar, se equivocam, pois antes mesmo do golpe de 1964 já se pensava em uma educação voltada para o mercado, com foco estrutural mercantilista. Os governos militares apenas potencializaram esta formação profissional.

As aspirações democráticas são solapadas com o advento do golpe militar de 1964. Paulo Freire e outros intelectuais são exilados, divulgando suas ideias mundo afora. Os militares se opunham à ampliação das oportunidades de ensino, enquanto procuravam agradar aos interesses dos empresários, colocando na ilegalidade importantes movimentos sociais.

Em termos de produção acadêmica, é na virada da década de 1960 para 1970 que são criados programas de pós-graduação em educação no país - PUC-Rio (1965) e PUC-SP (1969) os primeiros. Nos anos 1980, com a criação do Grupo de Trabalho "História da Educação" da Associação Nacional de Pós-Graduação e Pesquisa em Educação e do Grupo de Estudos e Pesquisas "História, Sociedade e Educação no Brasil", há uma massiva produção de trabalhos acadêmicos em História da Educação no Brasil (VIDAL; FARIA FILHO, 2003).

Porém, em contrapartida de interesses, os novos cursos de educação tecnológica não foram tão bem-vindos pelos profissionais de engenharia e, também, por grande parte das instituições no país naquele momento.

Muitos profissionais e centros de pesquisas não acreditavam que cursos de curta duração dariam base científica aos novos profissionais, pois estavam apenas desencadeando 
um lado do ensino, o profissional e técnico, e deixando de lado a prática científica da educação (BRANDÃO, 2009).

Percebe-se que, desde 1963 até 2016, em mais de 50 anos, este embate entre ciência e técnica ainda está em evidência. Essa é uma preocupação central na formação desse profissional.

\begin{abstract}
A solução encontrada pelo governo militar veio através de um decreto, em 1969 - portanto já com base na lei da reforma universitária de 1968 -, onde as Escolas Técnicas Federais foram "autorizadas a organizar e manter cursos de curta duração, destinados a proporcionar formação básica de nível superior e correspondentes às necessidades e características dos mercados de trabalho regional e nacional - Decreto-lei 547, de 18 de abril de 1969 (BRANDÃO, 2009, p. 7).
\end{abstract}

Em 1979, foi desenvolvido o Plano Setorial de Educação 1972/1974, sob n¹9, que expande a criação dos cursos de curta duração, a todas as áreas das ciências, para fomentar o desenvolvimento da sociedade (PETEROSSI, 1980, p. 36).

O que aconteceu no Brasil em relação à engenharia de operação foi decorrente a uma forte resistência por parte dos profissionais organizados desta área, fazendo com que fosse necessária uma espécie de correção do rumo nesta área; assim, os esforços do Estado voltaram-se para o que, a partir de 1973, começará a ser difundido como 'Cursos Superiores de Tecnologia', dando-se aos diplomados pelos mesmos a denominação de 'Tecnólogos. (BRANDÃO, 2009, p. 10).

A nomenclatura dos egressos dos cursos de curta duração foi modificada, deliberando uma denominação que conhecemos hoje de tecnólogos ou profissionais de Ensino Superior de Tecnologia.

Pode-se dizer que o início dos cursos de curta duração foi apenas realizado e conduzido pelas instituições federais de ensino, não deixando o ensino privado ainda no Brasil ministrar este tipo de educação em curta duração. Os Cursos Superiores de Tecnologia (CST) foram explorados com mais intensidade no Brasil na década de 1990, tanto pelo setor público quanto pelo privado, particularmente pelas grandes instituições privadas de ensino no país.

Sobre o grande crescimento dessa modalidade de ensino superior de tecnologia, Takahashi (2010), descreve:

Os CSTs tiveram um significativo crescimento quanto ao número de vagas, de alunos matriculados e de instituições ofertantes, nos últimos cinco anos no Brasil. [...]. A principal diferença entre os cursos de graduação tecnológicos, que conferem o diploma de tecnólogo, e os cursos tradicionais de Ensino Superior, que conferem o diploma de licenciatura ou bacharel, 
está na proposta e nos propósitos de cada um. Os cursos tecnológicos vêm atender a uma demanda do mercado por especialistas dentro de uma área de conhecimento e estão orientados por características como foco, rapidez e flexibilidade [...]. Os CSTs são, portanto, cursos distintos das graduações tradicionais (Parecer CNE/CES no 436/2001), e seus concluintes ficam aptos a prosseguir seus estudos em nível de pós-graduação (Revista de Administração Pública — Rio de Janeiro 44(2):385-414, mar./abr. 2010).

Em 1978, com a Lei nº 6.545, três Escolas Técnicas Federais (Paraná, Minas Gerais e Rio de Janeiro) são transformadas em Centros Federais de Educação Tecnológica - CEFETs, conferindo a estas instituições mais uma atribuição, a de formar engenheiros de operação e tecnólogos, processo esse que se estende às outras instituições bem mais tarde (BRASIL, 2011).

Na atual Lei de Diretrizes e Bases da Educação (LDB nº 9.394/96, Cap. III, art. 39): “A educação profissional integrada às diferentes formas de educação, ao trabalho, à ciência e à tecnologia conduz ao permanente desenvolvimento de aptidões para a vida produtiva". (BRASIL, 1996, p. 10).

Com a expansão dos CST pelo país, o Ministério da Educação - MEC faz uma reformulação na Educação Profissional; com os Decretos no 5.224 e $n^{\circ} 5.225$ (BRASIL, 2004), levando os CEFETs à condição das Universidades Públicas, ou seja, Institutos Federais de Educação Superior. Em 2007, foi lançada a segunda fase do Plano de Expansão da Rede Federal de Educação Profissional e Tecnológica, tendo como meta entregar à população mais 150 novas unidades, perfazendo um total de 354 unidades até o final de 2010, cobrindo todas as regiões do país, oferecendo cursos de qualificação, de ensino técnico, superior e de pósgraduação, sintonizados com as necessidades de desenvolvimento local e regional. Contudo, atualmente, tem-se uma relação total de 18 CEFETs e suas 33 Unidades de Ensino - UNEDs, vinculadas aos CEFETs.

O enfoque dado à Educação Profissionalizante teve em seu processo histórico várias alterações, ora se apresenta com enfoque de preconceito social, ora de assistencialismo. Logo em seguida, na busca pela superação dos enfoques anteriores, se lança sobre o discurso de inclusão social e democratização dos bens sociais. Existem várias expressões que tentam, por meio da história, imprimir significado à educação profissional: formação profissional ou técnico-profissional, educação industrial ou técnico-industrial, qualificação, requalificação e capacitação. Os referidos termos ganham complexidade e novos sentidos levando-se em conta a nova realidade produtiva e a nova reorganização dos processos de trabalho. 
O tema referente à educação profissional e tecnológica no Brasil é amplo e genérico, pois abrange uma amplitude de conceitos, discussões e leis sobre educação no âmbito de formação profissional que extrapola esta pesquisa, que tem como ênfase compreender como foi inserida a educação tecnológica no Brasil e os seus amparos legais.

Delimitando a pesquisa e lembrando que não é nosso objeto estudar a criação dos Institutos Federais em 2008, no entanto, no aspecto de legislação que apoiasse e regulamentasse a educação tecnológica no Brasil, se faz necessário reforçarmos o contexto histórico. Algumas leis e decretos davam indícios de que esse tema mereceria atenção especial, como percebido no Decreto-Lei No. 547, de 18 de abril de 1969, em que o então Presidente da República, Marechal Arthur da Costa e Silva, usando das suas atribuições decreta, em seu art. $1^{\circ}$, que as escolas técnicas federais, mantidas pelo Ministério de Educação e Cultura, poderiam ser autorizadas a organizar e manter cursos de curta duração, destinados a proporcionar formação profissional básica de nível superior e correspondente às necessidades e características dos mercados de trabalho regional e nacional. A Constituição Federal de 1988, quando trata da Educação em seu Capítulo III - Seção I, reforça esse aspecto e preocupação com a formação para o mercado de trabalho, especificamente no art. 214, quando faz a seguinte referência:

\begin{abstract}
A lei estabelecerá o plano nacional de educação, de duração plurianual, visando à articulação e ao desenvolvimento do ensino em seus diversos níveis e à integração das ações do Poder Público que conduzam a: I erradicação do analfabetismo; II - universalização do atendimento escolar; III - melhoria da qualidade de ensino; IV - formação para o trabalho; V promoção humanística, científica e tecnológica do País.
\end{abstract}

Observava-se, então, uma preocupação em destinar formação profissional superior em consonância com as demandas da necessidade de mão de obra especializada sinalizadas pelo mercado. Porém, essa atenção só foi evidenciada na Lei 9.394 de 20 de dezembro de 1996, sancionada pelo então Presidente da República Fernando Henrique Cardoso, que estabelecia as diretrizes e bases da educação nacional. Inicia-se, então, uma nova fase para consolidar a educação tecnológica no Brasil, que desencadeou não somente a sua regulamentação com a promulgação da lei, mas uma série de leis complementares, decretos, portarias, pareceres, resoluções e medidas provisórias que fortaleceram o propósito e melhor entendimento dessa modalidade de educação. 
As políticas públicas para a educação profissional e para o ensino tecnológico têm se desenvolvido desde a década de 1970 no sentido de tornar sistemático esse ensino na escola, incorporando-o à condição básica para a cidadania e para a preparação do aluno:

\begin{abstract}
Até meados da década de setenta, deste século, a formação profissional limitava-se ao treinamento para a produção em série e padronizada, com a incorporação maciça de operários semiqualificados, adaptados aos postos de trabalho, desempenhando tarefas simples, rotineiras e previamente especificadas e delimitadas. Apenas uma minoria de trabalhadores precisava contar com competências em níveis de maior complexibilidade, em virtude da rígida separação entre o planejamento e a execução. Havia pouca margem de autonomia para o trabalhador, uma vez que o monopólio do conhecimento técnico e organizacional cabia, quase sempre, apenas aos níveis gerenciais. A baixa escolaridade da massa trabalhadora não era considerada entrave significativo à expansão econômica (BRASIL, 1999, p. $3)$.
\end{abstract}

Na década de 1980 já se ouviria falar em gestão e em educação para o mercado de trabalho, o que implicava em um cenário econômico diferente e produtivo, em parte também por conta da crise mundial que gerou uma expectativa de renovação do mercado de trabalho.

Mas foi na década de 1990 que surgiram propostas mais importantes, com o avanço da informática e o desenvolvimento mais acelerado das tecnologias, que demandavam um incremento de técnicos e tecnólogos que viessem a formar um mercado de trabalho maior na área técnica e tecnológica.

A complexidade das novas tecnologias de comunicação e de informação foram agregadas à prestação de serviços e ao mercado globalizado. Assim, a formação dos técnicos começou a requerer bases educacionais mais sólidas, educação profissional básica para os que não eram qualificados e qualificação profissional para técnicos.

Segundo o Parecer CNE/CEB Nº 16/99 não se pode mais ver a educação profissional de forma simples, como instrumento político assistencialista ou ajustado apenas aos interesses empresariais.

Mas sim, como importante estratégia para que os cidadãos tenham efetivo acesso às conquistas científicas e tecnológicas da sociedade. Impõe-se a superação do enfoque tradicional da formação profissional baseado apenas na preparação para execução de um determinado conjunto de tarefas. A educação profissional requer, além do domínio operacional de um determinado fazer, a compreensão global do processo produtivo, com a apreensão do saber tecnológico, a valorização da cultura do trabalho e a mobilização dos valores necessários à tomada de decisões (BRASIL, 1999. p. 4). 
Contemporaneamente, podemos falar em uma nova educação profissional, não porque ela tenha mudado seu objetivo, mas porque ela mudou sua feição.

Entre os pressupostos da educação técnica, identificamos a articulação entre a educação básica e o ensino profissional ou tecnológico. Esta articulação adquiriu tanto características científico-tecnológicas como, também, características humanísticas, e essa foi uma resposta aos mecanismos restritivos do acesso à educação superior. Entretanto, a questão da articulação entre ensino básico e ensino médio e técnico/tecnológico deve levar em conta que ainda vigem como pano de fundo as velhas concepções sobre a formação da mão de obra de mercado voltada para as classes menos favorecidas (CÂMARA, 2010).

Nesse cenário, o papel do professor é complexo e não pode manter-se restrito a questões tipicamente escolares. De modo que é preciso considerar o cenário socioeconômico para que se formulem intervenções que sejam concebidas para uma escola que não se subordina à política educativa temporária dos governos (CÂMARA, 2010).

Segundo Pimenta e Anastasiou (2002), a metodologia de ensino superior no Brasil atualmente se encontra baseada nas primeiras iniciativas didáticas voltadas para a educação nas universidades dos modelos europeus, dentre os principais, o jesuítico, o francês e o alemão, exercendo importante influência até os dias de hoje. No entanto, esses modelos sofreram alterações, tornando os objetivos mais exigentes e complexos, visando o aumento da qualidade do ensino superior no país.

O ensino superior, pela sua constituição pedagógica se apresenta como um ato complexo, variando desde o processo de esforço a partir de necessidades formativas, até o esforço para se adequar a determinadas metodologias, que se desenvolve num momento histórico de grande oportunidade para a educação e que se apropria de uma diversidade teórica rica que marca de forma verdadeiramente positiva o desenvolvimento da formação de professores para o ensino superior (CÂMARA, 2010, p. 3).

A missão do ensino superior é disponibilizar à sociedade um ensino altamente qualitativo e eficaz na aquisição de conhecimento teórico e prático, necessário para a formação profissional do indivíduo, fazendo com que o mesmo esteja apto a atender as exigências do mercado. Dessa maneira, a sala de aula funciona como importante ferramenta ao fortalecimento do processo de ensino-aprendizagem, onde o educando poderá lidar com suas habilidades e capacidades, desenvolvendo sua perspectiva científica e seu senso crítico (MASETTO, 2008). 
De acordo com Masetto (2008, p. 14) "a função do Ensino Superior é de criar situações favoráveis ao desenvolvimento dos aprendizes nas diferentes áreas do conhecimento, no aspecto afetivo-emocional, nas habilidades e nas atitudes e valores".

A educação neste nível exige profissionais cujas funções devem acompanhar as diferentes e constantes mudanças em sala de aula, onde a formação e as habilidades do docente devem partir de atividades qualificadas, uma vez que são fundamentais para que os resultados das aulas sejam efetivos e positivos (MASETTO, 2008).

A didática do ensino superior exige um processo de ensino-aprendizado otimizado e consistente, onde os alunos adquirem o conhecimento de modo satisfatório para si mesmos e para os profissionais responsáveis por sua avaliação ao final do período letivo.

Conforme ressalta Costa (2008, p. 45), é de responsabilidade do ensino superior “instigar o educando a se preocupar com a valorização do conhecimento, a atualização contínua, a pesquisa, o estudo, a cooperação, a solidariedade entre educador e educando, a criatividade, o trabalho em equipe e o pensamento crítico". Através desta afirmação, observase que é de extrema importância que os docentes desempenhem suas funções de educadores com base em estratégias didáticas democráticas e autônomas.

No âmbito da Educação Superior a qualidade profissional prescinde do conteúdo/forma técnica, na medida em que ela é entendida como instrumento pedagógico reflexivo, organizativo e contextualizado do trabalho pedagógico e como veiculadora e produtora de significados e sentidos sociopolíticos e culturais (TORRES, 2006, p. 32).

É preciso ressaltar que a modernização mais importante para o desenvolvimento da sociedade se dá na área da educação, no entanto, ocorre de maneira gradativa e bastante lenta, pois engloba inúmeras transformações associadas a novos paradigmas, comportamentos e posturas, responsáveis por mudar as dimensões humanas sociais e culturais. Este processo é fundamental para o fortalecimento da cidadania e da democracia na sociedade (SANTOS, 2004).

Em uma tentativa de síntese, podemos dizer que a educação tecnológica no Brasil seguiu um percurso, como apresentamos no quadro 1, baseado em pesquisa realizada por Luiz Alberto Azevedo (2011), na Universidade Federal de Santa Catarina, denominada "De CEFET a IFET. Cursos Superiores de Tecnologia no Centro Federal de Educação Tecnológica de Santa Catarina: gênese de uma nova Institucionalidade?”

Quadro 1: O ensino de ofícios, o ensino industrial e o ensino profissionalizante de nível superior no Brasil. 


\begin{tabular}{|c|c|c|}
\hline $\begin{array}{l}\text { Tipo de } \\
\text { ensino }\end{array}$ & Período & Características \\
\hline De ofícios & \begin{tabular}{|l|} 
período \\
colonial
\end{tabular} & $\begin{array}{l}\text { Na Europa, existiu o sistema de aprendizagem corporativa: ocorria } \\
\text { diretamente no trabalho, ao qual o "aprendiz", geralmente na faixa etária } \\
\text { entre os } 12 \text { e } 15 \text { anos de idade, vinculava-se e assim "passava a morar na } \\
\text { oficina ou na residência do mestre - que eram frequentemente juntas - e } \\
\text { era submetido à vigilância, à disciplina e aos castigos físicos do mestre", } \\
\text { mediante contribuição estabelecida pela corporação que o pai deveria } \\
\text { pagar ao mestre. No Brasil existiu a transmissão de conhecimentos } \\
\text { (primeira etapa); oficiais ou companheiros", que "ascendiam de posto } \\
\text { quando passavam satisfatoriamente pelo aprendizado e, às vezes, } \\
\text { também tivessem trabalhado vários anos como operário." Nesse } \\
\text { contexto, "o oficial alugava seu trabalho através de contrato, verbal ou } \\
\text { escrito, mediante um juramento de bem cumprir as obrigações do ofício } \\
\text { e de denunciar infrações de que viesse a tomar conhecimento. Durante o } \\
\text { império, segundo Luís Antônio Cunha (2000, p. 91)) "desde os tempos } \\
\text { coloniais, quando um empreendimento manufatureiro de grande porte } \\
\text { exigia um contingente de trabalhadores não disponíveis, o Estado coagia } \\
\text { homens livres a se transformarem em artífices. "Não com quaisquer } \\
\text { homens livres, mas com aqueles que social e politicamente não estavam } \\
\text { em condições de opor resistência", e que uma dessas institucionalidades, } \\
\text { considerando sua contribuição, foi o "Colégio das Fábricas", instituído } \\
\text { em } 1809 \text {, no Rio de Janeiro. }\end{array}$ \\
\hline Industrial & $\begin{array}{l}\text { Sobretudo nos } \\
\text { governos de } \\
\text { Getúlio } \\
\text { Vargas (1930- } \\
1945), \\
\text { continuando } \\
\text { no governo de } \\
\text { José Linhares } \\
\text { (1945-1946) e } \\
\text { no governo de } \\
\text { Eurico Gaspar } \\
\text { Dutra (1946- } \\
\text { 1951), mas } \\
\text { ainda na } \\
\text { existente na } \\
\text { contempora- } \\
\text { neidade. } \\
\end{array}$ & $\begin{array}{l}\text { Buscava-se a formação para o trabalho indispensável às necessidades do } \\
\text { sistema produtivo, como previa a Lei Orgânica do Ensino Industrial, o } \\
\text { Decreto-Lei no 4.073/194. Citando Shiroma; Moraes; Evangelista } \\
\text { (2007), o autor da tese afirma que para efetivar o ensino industrial - a } \\
\text { mais urgente demanda de uma economia que acelerava o processo de } \\
\text { substituição de importações e destinado a uma parcela da classe operária } \\
\text { já engajada no processo fabril -, por exemplo, o governo se obrigou a } \\
\text { recorrer à Confederação Nacional da Indústria (CNI), criando um } \\
\text { sistema paralelo ao ensino oficial, o Serviço Nacional dos Industriários, } \\
\text { posteriormente Serviço Nacional de Aprendizagem Industrial -SENAI. } \\
\text { Um conjunto de Leis Orgânicas da Educação Nacional estabeleciam uma } \\
\text { distinção fundamental entre escolas industriais de nível médio e de } \\
\text { caráter tecnológico, "destinadas à formação para o trabalho complexo" e, } \\
\text { numa outra perspectiva de ensino, o "profissionalizante, representado } \\
\text { pelos cursos de aprendizagem e de formação básica (treinamento), } \\
\text { orientados para a formação direta e imediata da força de trabalho que se } \\
\text { incorporava crescentemente à vida urbano-industrial do país. }\end{array}$ \\
\hline $\begin{array}{l}\text { Profissionali- } \\
\text { zante de nível } \\
\text { superior }\end{array}$ & $\begin{array}{l}\text { Sobretudo } \\
\text { décadas de } \\
1960 \text { e } 1970\end{array}$ & $\begin{array}{l}\text { Generalização da formação para o trabalho simples e para o trabalho } \\
\text { complexo se acelera no decorrer do século XX, a partir do momento em } \\
\text { que o Estado capitalista assume a organização dos sistemas educacionais } \\
\text { com vistas a garantir "o aumento da produtividade da força de trabalho } \\
\text { em tempos de extração de mais-valia relativa e a responder às pressões } \\
\text { de amplos segmentos da população urbana por acesso à educação. É } \\
\text { perceptível porque cursos no ramo tecnológico eram caracterizados por } \\
\text { uma relação mais estreita entre educação e produção de bens e serviços, } \\
\text { [...], tendo como objetivo a formação de especialistas e de dirigentes } \\
\text { para o sistema produtivo. A partir da publicação da Lei no } 4.024 / 1961 \\
\text { pelo governo Goulart, o ensino industrial, com a implantação dos cursos } \\
\text { de engenharia de operação, sofre uma reforma para ensino técnico e de } \\
\text { "nível superior", mediante uma sequência de ações e legislações } \\
\text { necessárias ao funcionamento de cursos dessa natureza, assim como sua }\end{array}$ \\
\hline
\end{tabular}

RPGE- Revista on line de Política e Gestão Educacional, Araraquara, v. 22, n. 3, p. 992-1046, set./dez. 2018. E-ISSN:1519-9029. 


\begin{tabular}{|c|c|c|}
\hline $\begin{array}{c}\text { Tipo de } \\
\text { ensino }\end{array}$ & Período & \multicolumn{1}{|c|}{ Características } \\
\hline \multirow{2}{*}{} & & $\begin{array}{l}\text { organização para atender ao propósito vislumbrado pelo MEC, ou seja, o } \\
\text { mercado de trabalho. O governo Costa e Silva publica o Decreto-Lei no }\end{array}$ \\
$547 / 1969$ (re)definindo o funcionamento dos cursos profissionais \\
superiores de curta duração e deixando evidenciado que esses são \\
"destinados a proporcionar formação profissional básica de nível \\
superior e correspondentes às necessidades e características dos \\
mercados de trabalho regional e nacional."
\end{tabular}

Fonte: Luiz Alberto Azevedo, De CEFET a IFET. Cursos Superiores de Tecnologia no Centro Federal de Educação Tecnológica de Santa Catarina: gênese de uma nova Institucionalidade? (2011).

No Brasil, existem inúmeros tipos de instituições de ensino superior, tanto na esfera pública como na privada, como: universidades, faculdades integradas, centros universitários, instituições isoladas. Lembrando que o ensino superior de cursos de tecnologia de curta duração não é apenas um curso oferecido apenas por instituições públicas. As privadas também podem ofertá-los, desde que sejam aprovados pelo MEC. As instituições universitárias federais, no entanto, não precisam dessa aprovação.

A primeira iniciativa oficial de ensino profissionalizante na República foi a criação, em 1909, pelo presidente Nilo Peçanha, de dezenove escolas de aprendizes artífices, a Rede Federal de Educação Profissional, Científica e Tecnológica. O surgimento no Brasil da modalidade conhecida pela expressão ensino técnico se dá durante o governo de Getúlio Vargas, na década de 1930: “[...] já existia o curso técnico comercial, com duração de um a três anos que [...] equivalia ao curso secundário (ginasial) com duração de cinco anos e se configurava como uma opção para os concluintes do antigo primário” (SOUZA, 2015).

Souza (2015) produziu um verbete que traz a evolução da legislação do ensino técnico, desde 1931 a 1982. A legislação de então até hoje foi obtida no portal do MEC, no Conselho Nacional de Educação (CNE), na Câmara da Educação Básica, na Universidade Tecnológica Federal do Paraná (UTFPR) entre outras fontes. Os dados, sumarizados, vêm a seguir.

\section{- Reforma Francisco Campos (1931-2) - cria-se o Curso Superior de}

Administração e Finanças. Quem concluía o curso técnico comercial podia dar continuidade aos estudos.

- Reforma Capanema (1942-6), promulgação da Leis Orgânicas do Ensino, criação de escolas técnicas secundaristas que possibilitam acesso ao ensino superior, no entanto, regulamentado pela Lei $\mathrm{n}^{\circ} 1.821$, de 12 de março de 1953. Uma das respostas populistas aos movimentos populares e da classe média urbana em busca de condições de mobilidade social. Surgem Senai e Senac. 
- $\quad$ Lei de Diretrizes e Bases da Educação Nacional (LDB), Lei no 4.024 de 20 de dezembro de 1961 -com seu apelo de industrialização, permite o acesso livre ao ensino superior. $\mathrm{O}$ ensino profissionalizante ganha destaque no cenário educacional

- Lei $\mathrm{n}^{\mathrm{o}} 5.692$ de 11/08/1971, que implantou, junto com a Lei $\mathrm{n}^{\mathrm{o}} 5.540$ de 28/11/1968, “[...] novas políticas educacionais para o ensino superior e novas diretrizes e bases para o ensino de $1^{\circ}$ e $2^{\circ}$ graus". A lei de 1971 obrigou à profissionalização no ensino de $2^{\circ}$ grau para qualificar trabalhadores requeridos pelos programas de desenvolvimento em vários setores econômicos.

- Reforma pela Lei no 7.044 de 18 de outubro de 1982 - “[...] a profissionalização no ensino de $2^{\circ}$ grau deixou de ser obrigatória".

- Última LDB, Lei Federal n 9.394, de 20 de dezembro de 1996 - dá as Diretrizes e Bases da Educação Nacional, com destaque para os artigos 39 a 42 do capítulo III do título V.

- $\quad$ Decreto Federal $n^{\circ} 2.208$, de 17 de abril de 1997 - regulamenta o $§ 2^{\circ}$ do artigo 36 e os artigos 39 a 42 da LDB. Com currículo independente do ensino médio, possibilita cursar o Ensino Médio simultaneamente: “A desvinculação entre o ensino médio e o ensino técnico possibilita uma flexibilização e significativa ampliação das oportunidades de educação profissional no nível do ensino médio. Por se tratar de uma alteração estrutural é necessário tecer algumas considerações a este respeito" (CNE/CEB, 1997).

- Portaria MEC n 646, de 14 de maio de 1997 - específica para a rede federal de educação tecnológica.

- Resolução CEB nº 04 01/12/1999 - dá as Diretrizes Curriculares Nacionais para a Educação Profissional de Nível Técnico.

- Decreto $n^{\circ} 5.154$ 23/07/2004 - regulamenta os artigos 36, 39 e 41 da Lei 9.394 - LDB.

- Resolução CEB nº 01 01/02/2005 - atualiza as Diretrizes Curriculares Nacionais definidas pelo CNE para o Ensino Médio e para a Educação Profissional Técnica de nível médio, às disposições do Decreto n. ${ }^{\circ}$ 5.154/2004.

- Resolução CEB/CNE n ${ }^{\circ}$ 1, de 05 de dezembro de 2014 - reclassifica o Catálogo Nacional de Cursos Técnicos, determinando para instituições públicas e privadas de Educação Profissional e Tecnológica a oferta de cursos técnicos de Nível Médio em caráter experimental, a partir das determinações da LDB/96 e Resolução CNE/CEB nº 6/2012.

Assim, podemos analisar que o sistema educacional brasileiro foi se adaptando à época que estava sendo vivenciada ao longo do tempo em nossa história. Foram 
estabelecendo leis, regulamentos, normas, para demonstrar uma resposta aos anseios dos mercados internacionais e fomentar a indústria brasileira e formação de mão de obra, de acordo com a demanda de profissionais na área. Podemos interpretar que, de certa forma, o ensino técnico poderia contribuir, dentro de seus limites, para o desenvolvimento da economia nacional.

O Decreto $\mathrm{n}^{\mathrm{o}} 5.154 / 2004$, em seu artigo $5^{\circ}$, destaca que: "os cursos de educação profissional tecnológica de graduação e pós-graduação organizar-se-ão, no que concerne aos objetivos, características e duração, de acordo com as diretrizes curriculares nacionais definidas pelo Conselho Nacional de Educação (BRASIL, 2004, p. 1). Esses cursos são regidos pelos seguintes pareceres:

Ano 2001 - Parecer CNE/CES nº 436/2001, aprovado em 2 de abril de 2001, refere-se às orientações sobre os Cursos Superiores de Tecnologia - Formação de Tecnólogo.

Ano 2002 - Parecer CNE/CP n. ${ }^{\circ}$ 29, de 3 de dezembro de 2002, refere-se às Diretrizes Curriculares Nacionais Gerais para a organização e o funcionamento dos cursos superiores de tecnologia.

Ano 2002 - Resolução CNE/CP n. ${ }^{\circ}$ 3, de 18 de dezembro de 2002, responsável por instituir as Diretrizes Curriculares Nacionais Gerais para a organização e o funcionamento dos cursos superiores de tecnologia.

Ano 2006 - Parecer CNE/CP nº 6, de 6 de abril de 2006, refere-se à solicitação do pronunciamento sobre Formação Acadêmica X Exercício Profissional.

Ano 2006 - Parecer CNE/CES nº 212/2006, aprovado em 10 de agosto de 2006, trata do aproveitamento de disciplinas cursadas no curso de Formação de Técnicos em Radiologia em Curso Superior de Tecnologia Radiológica.

Ano 2006 - Parecer CNE/CES n 277/2006, aprovado em 7 de dezembro de 2006, refere-se à nova forma de organização da Educação Profissional e Tecnológica de graduação.

Ano 2006 - Parecer CNE/CES nº 19/2008, aprovado em 31 de janeiro de 2008, trata sobre a Consulta do aproveitamento de competência de que trata o art. $9^{\circ}$ da Resolução $\mathrm{CNE} / \mathrm{CP} \mathrm{n}^{\circ}$ 3/2002, que institui as Diretrizes Curriculares Nacionais Gerais para a organização e o funcionamento dos cursos superiores de tecnologia.

Ano 2008 - Parecer CNE/CES n 90/2008, aprovado em 10 de abril de 2008, aborda a solicitação do CNE para que examine a questão do profissional formado pelo Curso Tecnológico em Resgate e Socorro, implantado em 2002.

Ano 2008 - Parecer CNE/CES nº 239/2008, aprovado em 6 de novembro de 2008, referente à carga horária das atividades complementares nos cursos superiores de tecnologia. 
O PNE (Plano Nacional de Educação) referente à Lei $n^{0} 13.005 / 2014$ é um instrumento de planejamento do Estado democrático de direito brasileiro, que orienta a execução e o aprimoramento de políticas públicas do setor. No artigo $2^{\circ}$, esse Plano apresenta dez diretrizes, elencadas a seguir:

I - erradicação do analfabetismo;

II - universalização do atendimento escolar;

III - superação das desigualdades educacionais, com ênfase na promoção da cidadania e na erradicação de todas as formas de discriminação;

IV - melhoria da qualidade da educação;

V - formação para o trabalho e para a cidadania, com ênfase nos valores morais e éticos em que se fundamenta a sociedade;

VI - promoção do princípio da gestão democrática da educação pública;

VII - promoção humanística, científica, cultural e tecnológica do País;

VIII - estabelecimento de meta de aplicação de recursos públicos em educação como proporção do Produto Interno Bruto - PIB, que assegure atendimento às necessidades de expansão, com padrão de qualidade e equidade;

IX - valorização dos (as) profissionais da educação;

$\mathrm{X}$ - promoção dos princípios do respeito aos direitos humanos, à diversidade e à sustentabilidade socioambiental (BRASIL, 2014, p. 1).

O referido PNE destaca como estratégia para alcançar a Meta 9 (de elevar a taxa de alfabetização da população):

Implementar programas de capacitação tecnológica da população jovem e
adulta, direcionados para os segmentos com baixos níveis de escolarização
formal e para os(as) alunos(as) com deficiência, articulando os sistemas de
ensino, a Rede Federal de Educação Profissional, Científica e Tecnológica,
as universidades, as cooperativas e as associações, por meio de ações de
extensão desenvolvidas em centros vocacionais tecnológicos, com
tecnologias assistivas que favoreçam a efetiva inclusão social e produtiva
dessa população (BRASIL, 2014).

Por outro lado, as metas 12, 13 e 14 do PNE-2014 também favorecem indiretamente os cursos superiores tecnológicos, visto que a meta 12 propõe a elevação da taxa bruta de matrícula no ensino superior, e a meta 13 , volta-se para a ampliação da proporção de mestres e doutores no ensino superior

Por princípio, o PNE deixa claro que a educação profissional que propõe (nela incluída os cursos técnicos e os tecnológicos) afasta-se daquela "historicamente demarcada pela divisão social do trabalho", em que uma educação geral atenderia um pequeno grupo de elite econômica, e uma outra, profissional, voltada para a classe trabalhadora. Tal distinção remonta ao apartamento "entre a propriedade dos meios de produção e a propriedade do trabalho, ou seja, a lógica de que alguns pensam, planejam, e outros executam”. Assim, faz-se 
necessário que a oferta de cursos tecnológicos (como os demais cursos profissionalizantes) baseie-se em uma concepção de uma educação que supere "a dualidade entre as culturas geral e técnica", assegurando a aprendizagem da ciência referente às diferentes técnicas que distinguem o processo do trabalho produtivo na contemporaneidade (BRASIL, 2014, p. 39).

\title{
Desafios para os Cursos Superiores de Tecnologia
}

\section{Sobre a formação do professor para os CSTs}

A formação superior em cursos de tecnologia é considerada um desafio. A carência acentuada de docentes com qualificação é um dos gargalos da expansão da educação tecnológica (e profissional) no país. E as ofertas de curso de qualificação nem sempre atendem ao perfil demandado. A tecnologia constitui uma ciência transdisciplinar na produção, utilização das TIC e demais fatos tecnológicos (MACHADO, 2008).

O perfil do professor na educação profissional demanda que seja:

\begin{abstract}
um sujeito da reflexão e da pesquisa, aberto ao trabalho coletivo e à ação crítica e cooperativa, comprometido com sua atualização permanente na área de formação específica e pedagógica, que tem plena compreensão do mundo do trabalho e das redes de relações que envolvem as modalidades, níveis e instâncias educacionais, conhecimento da sua profissão, de suas técnicas, bases tecnológicas e valores do trabalho, bem como dos limites e possibilidades do trabalho docente que realiza e precisa realizar (MACHADO, 2008, p. 17).
\end{abstract}

Em termos de conteúdo curricular na formação docente, alguns temas podem ser trabalhados transversalmente,

[...] (os específicos do campo tecnológico, os da educação geral e os de fundamentação pedagógica), tais como: a evolução histórica da tecnologia; tecnologia e desenvolvimento científico; tecnologia, qualidade de vida e desenvolvimento humano; ética e tecnologia; tecnologia e mundos do trabalho; tecnologia e impacto socioambiental (MACHADO, 2008, p. 20).

Sem descuidar do núcleo contextual, estrutural e integrador, como estabelecido pela Resolução CNE nº 2/97 (MACHADO, 2008), propõe uma organização:

- contextual - contempla conhecimentos do papel da escola, da estrutura e legislação básica e tecnológica e dos fundamentos da educação básica e profissional;

- estrutural - visa à compreensão do desenvolvimento do processo ensinoaprendizagem, dos conhecimentos específicos do campo tecnológico, da didática e 
da psicologia aplicadas à educação profissional;

- integradora - propõe uma ação reflexiva sobre a avaliação da aprendizagem, a metodologia e a prática de ensino profissional.

É relevante destacar a importância de se saber, portanto, qual a competência exigida pelo trabalho pedagógico e docente em seu campo de alcance. Essas características devem estar observadas nos projetos, programas, decretos e leis que dirigem a Educação. Deve-se assegurar o que se espera desse profissional em seu campo de trabalho.

O acesso ao Ensino Superior no Brasil teve como objetivo possibilitar uma consolidação da formação universitária no país, para melhorar as perspectivas atuais. Os cursos superiores de tecnologia foram criados para ampliar o número de profissionais capacitados para o mercado de trabalho, mas existem muitas controvérsias sobre a qualidade da formação tecnológica. O mais grave parece-nos ser essa importância na preparação para o mercado, deixando de abarcar, com igual ênfase, a formação crítica, social e reflexiva.

Os problemas que atualmente afligem a universidade no Brasil têm de ser entendidos num contexto maior de Estado brasileiro, desde a organização daquela até a racionalidade e legitimidade deste último. No elenco dos problemas institucionais, dentre outros, é possível arrolar os seguintes: curriculares; corpo docente; relação professor-aluno; infraestrutura para o ensino-aprendizagem; e avaliação dos resultados e condições do processo formativo, tendo em vista o compromisso social da universidade.

As limitações nas condições socioeconômicas de significativa parcela dos estudantes, interferindo em suas condições para estudo e dedicação às demais tarefas do curso superior, são um dos fatores que eleva a procura por Cursos Superiores de Tecnologia, pois os alunos têm a necessidade de uma formação especializada, num curto período de tempo, para poderem ingressar no mercado de trabalho, ou ainda, melhorar suas condições profissionais atuais.

É importante observar que existe um evidente descompasso entre a universidade e a realidade social brasileira. De um lado, porque a universidade não tem assumido o seu papel de agente estratégico do desenvolvimento nacional. De outro, porque também não tem contribuído, em certa medida, para a crítica acerca dos modelos de desenvolvimento até hoje implementados de forma autoritária no país.

A universidade brasileira precisa ficar atenta para não se situar à margem dos processos sociais, políticos e econômicos, voltada apenas aos seus objetivos internos, alheia às necessidades e reclamos da população. Ela não deve constituir-se como agência de uma modernização reflexa, que reflete projetos externos, muitas vezes contrários aos interesses da população brasileira. 
Porém, não podemos ignorar os avanços existentes em diversos centros de ensino. Cursos de formação tecnológica e profissionalizante evoluem para um nível de criticidade, aliada à formação profissional, sobretudo na pós-graduação. Generalizações ou afirmações maniqueístas não são, portanto, compatíveis com a realidade acadêmica.

Neste contexto, surge a necessidade de formar profissionais capazes de organizar situações de aprendizagem. Estudos sociológicos sobre as profissões demonstram uma evolução clara, e com a formação docente não poderia ser diferente. Atualmente, os professores devem ser profissionais na prática letiva, no sentido de serem formados para atender às necessidades rotineiras da prática docente.

É preciso analisar

as formas do pensar, do fazer pedagógico, bem como das funções e dos objetivos do [espaço escolar] hoje. Essas informações deverão ser buscadas, bem como a compreensão de como se produz o conhecimento, de como fazemos a leitura do mundo e das relações de poder; se faz necessário situarmos os conceitos principalmente de diversidade, de educação e de humano, para podermos pensar em promover uma formação docente inicial e continuada mais próxima à realidade, para a promoção da mesma, transformando assim o processo de ensino-aprendizagem mais efetivo e coerente às necessidades do Ser Humano e da Sociedade em que ele vive (ZYCH; VASSÃO, 2013, p. 817).

O professor exerce um importante papel no desenvolvimento global do aluno, podendo aguçar-lhe a vontade de vir ou não para a escola, conhecer e aprender mais, ou tolher suas expectativas tornando $\mathrm{o}$ ambiente escolar sem motivação, repleto de frustrações e experiências traumatizantes. Assim, cabe ao professor promover um ambiente acolhedor na sala de aula, permitindo que o aluno revele sua bagagem de conhecimentos, privilegiando um harmonioso espaço para o saber, propício ao desenvolvimento do aluno em sua plenitude. Essa promoção de um ambiente acolhedor e motivador, onde o aluno possa se expressar, ou seja, a democratização do saber, foi uma ideia abarcada pelas obras de Paulo Freire.

A formação acadêmica de professores está diretamente relacionada à qualidade social da educação no Brasil, inclusive visando a melhoria da elaboração do projeto políticopedagógico que seja comprometido com o processo de democratização social visando a formação para o exercício da cidadania.

A formação continuada dos docentes é um processo cotidiano de construção do saber, que contribui diretamente com o seu desenvolvimento profissional permanente, enfatizando a importância à satisfação das necessidades formativas como cidadãos. Se considerarmos que a escola tem autonomia para a consolidação da formação dos alunos e dos educadores, é 
possível afirmar que todos devem estar comprometidos com a construção do saber e maior aquisição de conhecimento.

Os professores devem procurar compreender os valores individuais e sociais que são essenciais para a sua formação. Eles também devem considerar que a formação continuada não é um evento que deteriora uma proposta formativa anterior. Ao contrário, é uma soma de conhecimentos e experiências que contribuirão para a excelência na prática docente.

$\mathrm{Na}$ formação do professor, o cotidiano precisa ser desvendado, uma vez que, se a opção é por uma prática docente continuada, é sugerida uma recolocação do conhecimento na perspectiva histórico-social.

Outro fator importante em uma proposta formativa de avanço na instituição escolar é a participação coletiva na gestão da escola e das ações coletivas do trabalho docente. Esse é um elemento indispensável que orientará o aperfeiçoamento profissional e da instituição escolar em que atua profissionalmente.

A formação acadêmica continuada do professor deve promover a revisão de conteúdos arcaicos, pouco relevantes e o reconhecimento do educador como um ser contextualizado socialmente que irá auxiliar na busca de uma nova ordem pedagógica e de intervenções da realidade escolar.

Atualmente, existem novos desafios para a educação, pois o mundo globalizado, cercado de tecnologias e aparatos, também é fragmentado, desigual, multiculturalista, com mudanças constantes e rápidas que exigem maior flexibilidade, autonomia, criatividade e capacidade para a tomada de decisões.

Todos esses fatores também exigem dos educadores uma nova postura, pois precisam acompanhar os avanços tecnológicos e as demandas frente às novas perspectivas da educação em relação à globalização, aos avanços tecnológicos, políticos, sociais e científicos, além de reconhecer que os alunos, atualmente, possuem uma postura diferenciada dos alunos de gerações anteriores, pois são mais bem informados devido ao uso de recursos tecnológicos em seu cotidiano.

A escola tornou-se alvo de mudanças e, consequentemente, é preciso repensar sua estrutura, suas finalidades e sua forma de atuação. Nesse contexto, a formação acadêmica continuada do professor é ponto essencial que exige reflexão e mudanças urgentes.

De modo geral, as bases da formação de professores são estruturadas por tendências progressistas da educação, baseadas em linhas ideológicas de vertentes críticas, que objetivam a formação do cidadão. Os pressupostos dessa formação têm como premissa a preparação de professores conscientes de seus direitos e deveres, aptos a participarem ativamente como 
sujeitos históricos da sociedade em que atuam. Desse modo, os futuros educadores são cidadãos que se formam com o objetivo de formar outros cidadãos.

Mas, esses professores, que vêm de uma formação progressista e se deparam com a imposição de uma nova ordem mundial alicerçada no conservadorismo, precisam superar os obstáculos, superando o choque entre a teoria e a prática. Isso somente é possível com a formação acadêmica continuada. Isso ocorre porque, apesar das teorias e práticas progressistas relacionadas à educação, as legislações e diretrizes ainda são conservadoras e baseadas no ensino mecanicista, técnico, de conteúdos, onde apenas o professor é soberano em sala de aula, omitindo e excluindo a presença dos alunos.

Assim, é possível afirmar que a formação é um processo cultural que acompanha o ser humano por toda sua existência. Se o histórico de vida do professor é importante para o seu processo formativo, consequentemente, a formação para o exercício da docência começa muito antes do ingresso no curso superior, bem como não esgota quando ele termina.

O exercício docente exige que o profissional de educação tenha compromisso com a transformação social e uma postura ética durante toda a sua carreira. Toda essa demanda para a formação não pode ser cumprida apenas com a formação tecnológica. Um curso superior de tecnologia pode ser um marco inicial para a formação e ingresso no mercado de trabalho, contudo, é preciso que o profissional invista na continuidade de sua formação acadêmica, para melhorar sua atuação profissional.

\section{Os limites, as críticas}

A formação tecnológica na perspectiva de adaptação aos objetivos do mercado, sobre a educação no Brasil, desde a colônia, sempre teve duas vertentes educacionais, uma para atender as demandas das elites e outra para a classe trabalhadora. A formação da classe trabalhadora tem sido voltada para o mercado de trabalho, para a especialização da mão de obra.

Com o passar do tempo, os nomes dos cursos mudaram, as formas de ensino modificaram-se, mas a formação de mão de obra para o mercado de trabalho, voltada para a classe trabalhadora ainda prevalece.

Frigotto (2007, p. 1130-1131) corrobora as assertivas supracitadas ao afirmar que “[...] por trás de cada conceito de conteúdo ou de organização e financiamento da educação profissional e tecnológica, aninha-se um longo embate histórico de caráter político-ideológico que expressa relações de poder que se reiteram em nosso processo histórico".

As análises sobre a educação no Brasil têm cometido o equívoco de tratar a formação 
acadêmica em si mesma, esquecendo-se de toda a história de colonialismo, escravatura e o capitalismo que atualmente continua a separar as elites da classe trabalhadora.

A necessidade de ampliar as estatísticas de nível de ensino por parte dos gestores e a demanda por mão de obra especializada fez com que os governantes, ao longo de toda a história do Brasil, implementassem políticas públicas que relegaram a educação básica e, consequentemente, a educação profissional e tecnológica.

A universalização da educação básica visa a formação do cidadão produtivo, submisso e adaptado às demandas do mercado de trabalho e do capitalismo. Mesmo com tantas reformas no contexto da educação brasileira, a formação social desigual prevalece e dificulta a realização de mudanças efetivas, que possam privilegiar a qualidade de ensino em detrimento da ampliação das estatísticas.

A classe trabalhadora brasileira, segundo Frigotto (2007, p. 1136), nunca teve uma escolaridade e formação técnico-profisssional de qualidade: "O campo da educação teve um ciclo de reformas completo para adaptar-se ao projeto do golpe civil-militar. Sob a égide do economicismo e do pragmatismo, adotou-se a ideologia do capital humano, reiterando nossa vocação de cópia e mimetismo".

No contexto do pensamento pedagógico, no entanto, o capital humano não é considerado. Trata-se de uma política que busca uma ideologia que não é colocada em prática, uma vez que sua intenção é apenas a formação da classe trabalhadora para atender as demandas de mercado. O governo faz uma 'propaganda' de melhoria da qualidade do ensino, mas isso não ocorre na prática. Segundo Frigotto (2007, p. 1139),

Apenas cerca de $46 \%$ dos jovens têm acesso ao ensino médio, sendo que mais da metade destes o fazem no turno noturno e, grande parte, na modalidade de supletivo. Quando analisamos por região, a desigualdade aumenta. No campo, por exemplo, apenas $12 \%$ frequentam o ensino médio na idade/série correspondente, também com enormes desigualdades regionais.

A desigualdade e a dificuldade de os alunos permanecerem na escola e cursarem o ensino médio é uma consequência das desigualdades continentais prevalentes no Brasil. As políticas voltadas para a educação no Brasil não se preocupam com a ampliação da produção científica, técnica ou tecnológica, nem mesmo com o direito de cidadania. A preocupação é apenas com a formação de trabalhadores para atuar no mercado de trabalho. Não existe interesse na formação integral, de qualidade, voltada para o cidadão e sua atuação no cenário social e político. Esse tipo de ideologia é buscado e obtido apenas por aqueles que podem 
pagar pela educação de seus filhos, que frequentam as universidades em cursos regulares buscando uma formação integral. Os filhos da classe trabalhadora, por sua vez, necessitam de cursos rápidos, que priorizem a técnica, de modo que possam ingressar rapidamente no mercado de trabalho (FRIGOTTO, 2007).

A universalização do ensino não deve ser voltada para a formação de mão de obra, mas, sim, para a qualidade teórica, técnica e política. Isso deve valer para todos os brasileiros, todas as crianças e jovens têm o direito à educação, mas a uma educação de qualidade.

Em estudo recente, Frigotto (2016) confirmou suas assertivas realizadas em estudos anteriores (FRIGOTTO, 2007), de que o ensino fundamental é frágil e não atende as necessidades de aprendizagem dos alunos. A fragilidade da educação básica se reflete no ensino médio e, também, no ensino superior, sobretudo nos cursos superiores de tecnologia:

De fato, a educação básica e de nível médio no Brasil é precária e provoca reflexos na formação acadêmica de nível superior. Um aluno que cursa o ensino público no Brasil terá muitas dificuldades em acompanhar um curso de nível superior formal, em grandes universidades públicas federais ou estaduais, mas existe a demanda por formação. O que ocorre então: muitos alunos buscam a formação tecnológica, devido ao curto período de tempo para sua realização e devido à falta de conhecimento dos alunos para a compreensão de conceitos que não foram apreendidos nos níveis anteriores.

Como bem observou Frigotto (2016, p. 3),

É no bojo deste projeto que a educação básica universal e unitária se imporá como necessidade real com aportes substantivos de recursos para viabilizá-la e a educação profissional, não como mera adaptação às demandas do mercado, mas como direito subjetivo do trabalhador e necessidade dos sistemas produtivos. Isto demanda uma inversão do caráter privado que tem sido caracterizado historicamente. Trata-se de subordiná-la a uma gestão e controle públicos.

Brandão (2009) também tece suas críticas aos cursos superiores de tecnologia e de formação profissional ao afirmar que eles foram implantados como parte de uma estratégia política da década de 1960 que buscava a modernização.

A realidade no Brasil foi a implementação de uma formação baseada no modelo econômico de capitalismo dependente voltada ao oferecimento de uma formação denominada de 'nível superior' para diminuir as pressões populares por vagas nas universidades e, ao mesmo tempo, fornecer mão de obra para o mercado. Nesse cenário, o governo cumpre seu papel de mantenedor da escola pública, porém utilizando como incentivo o oferecimento de cursos que qualificariam os trabalhadores dentro dos limites necessários para "apenas - posto 
serem cursos de caráter terminal - operar e manter o equipamento e o projeto industrial importado, mas não para criar um projeto de desenvolvimento específico do Brasil" (BRANDÃO, 2009, p. 9).

Desde a década de 1960, várias reformas educacionais ocorreram no Brasil, mas o cerne da educação prevalece, a formação de mão de obra para o mercado de trabalho, sem a preocupação de uma formação de qualidade. Até os dias atuais prevalece a dualidade na história da educação e, como em outros momentos da história brasileira, eleva-se um pouco mais o nível da educação profissional, que antes era realizada no nível básico, depois passou para o nível médio e agora também está no nível superior. Mas continua a formar o trabalhador para os interesses do mercado de trabalho, com uma formação fragmentada que não atende as suas reais necessidades de conhecimento, apenas permite que ele ingresse no mercado de trabalho com uma formação de nível superior. Trata-se de um novo modelo de formação da mão de obra, prevalente no Brasil do século XXI, que atende ao processo produtivo modernizado.

Como bem esclarece Brandão (2009), é uma necessidade de conformação política e cultural de indivíduos que aceitam e reproduzem o sistema e, consequentemente, o capitalismo.

Nessas reflexões, não podemos nos furtar a admitir que há um desenvolvimento, que algo já avançou. Nesse sentido, podemos destacar a existência de cursos tecnológicos que explicitam valores éticos, oferecem disciplinas da área de humanas voltadas para a formação político-crítica e cidadã, como observamos em cursos de pós-graduação de institutos federais de educação, ciência e tecnologia.

Podemos analisar os Cursos Superiores de Tecnologia por uma perspectiva da sociedade do conhecimento, a formação de nível superior para atender as demandas de mercado. Trata-se da necessidade de formação de um novo tipo de trabalhador para servir ao novo padrão mundial e nacional, que começou a surgir a partir das décadas de 1980 e 1990 que implicaram em mudanças sociais e educacionais. Essas mudanças culminaram numa série de medidas, leis, decretos, resoluções e pareceres, aliados aos programas governamentais para regulação e coordenação da execução de políticas públicas para a educação profissional e tecnológica. Mas, apesar de atender às demandas de mercado, a atual formação superior tecnológica possui a qualidade necessária para suprir as necessidades de conhecimento dos alunos? Esse tipo de formação atende à formação integral do cidadão?

A educação no Brasil assumiu um papel estratégico no desenvolvimento econômico e, também, no combate às desigualdades sociais, ao primar pela reinserção dos indivíduos às 
novas sociedades constituídas por meio da informação e saber. Consequentemente, todos os setores demandam investimentos em educação e são afetados pelas suas deficiências (SOUZA, 2012). Como bem observou Pacheco (2011), “a educação tornou-se imperativo como parte fundamental de um projeto nacional".

A nova dinâmica da sociedade demanda indivíduos com pensamento crítico e formação ética para contribuir com o desenvolvimento sustentável, e também com capacidades sólidas para sobreviver em um mercado de trabalho cada vez mais exigente. Por este motivo, as instituições de ensino superior passaram a investir em cursos tecnológicos como um novo formato de formação acadêmica, que produz profissionais para o mercado de trabalho com formação superior. A brecha entre o mercado de trabalho e a formação universitária se tornou um assunto polêmico, fonte de debate entre vários estudiosos como foi demonstrado ao longo deste estudo.

Segundo Souza (2012), o estudo de Castells (2008) é de grande importância, pois mostra como a sociedade do conhecimento aprofunda a discussão sobre a relevância da educação. Guzmán (2016) também afirma a importância desse autor nos estudos sobre a sociedade do conhecimento e a educação em nível superior.

Para Castells (2008), a sociedade atual possui um modo específico de desenvolvimento da informação, que é a ação do conhecimento sobre si mesmo. Assim, a sociedade e o ser humano estão continuamente aprendendo. Trata-se de um círculo virtuoso de interação das fontes de conhecimento da tecnologia e da aplicação destas para melhorar a geração do conhecimento e o processamento da informação.

A sociedade da informação, segundo Castells (2008), orienta-se para o desenvolvimento tecnológico e decide em direção à acumulação do conhecimento e em direção aos graus mais elevados de complexidade do processamento da informação. A busca do conhecimento e informação é o que caracteriza a função de desenvolver a tecnologia e ela tende a desenvolver-se através de paradigmas que vão se formando nos setores sociais que hegemonizam a sociedade. Porém, existe uma conexão especialmente estreita entre cultura, educação e forças produtivas, entre espírito e matéria.

Todos os fatores supracitados representam as atuais relações dos indivíduos com a sociedade e com o mercado de trabalho. Para se tornar empregáveis, os indivíduos buscam qualificação acadêmica, mas a necessidade de se manterem no mercado de trabalho e a falta de condições de realizar um curso tradicional conduzem os indivíduos aos cursos de formação superior tecnológica, o que atende as demandas do mercado, mas, nem sempre atende as de conhecimento dos indivíduos. 
Além disso, alguns professores que atuam nesses cursos superiores de tecnologia não estão devidamente preparados, pois possuem a formação técnica para atuar, mas não têm a formação docente necessária. Esse tipo de profissional está capacitado para transferir os conhecimentos técnicos para os alunos, mas isso não basta. Como bem observou Moura (2016), é preciso a formação humana integral que inclua ciência, trabalho, tecnologia e cultura como eixos indissociáveis.

Para Moura (2016, p. 37),

[...] é fundamental que se estabeleça um regime de cooperação mútua entre os sistemas de ensino e desses com outros órgãos e esferas de governo e da sociedade civil. Tal cooperação deve estar orientada a aproximar as instituições públicas que atuam nesse campo educativo entre si, visando a uma aproximação do seu conjunto com a sociedade e, em consequência, às suas demandas.

Uma didática reflexiva deve-se fazer presente na formação docente, para poder proporcionar ao futuro professor condições de interpretar a realidade a sua volta, suas ações e as consequências destas para si e para a comunidade escolar onde se insere como profissional docente.

\section{Considerações finais}

Este estudo abordou os desafios, as críticas e as controvérsias sobre os cursos superiores de tecnologia no Brasil. Frente à complexidade dos fenômenos sociais e os processos e estruturas impostos sobre a produção e gestão da vida cotidiana em toda a sociedade, o objetivo que predomina no ensino superior, como depreendemos do estudo realizado, sobretudo no que se refere aos cursos superiores de tecnologia, é a formação do profissional para atuar no mercado de trabalho.

Os avanços das tecnologias da informação e comunicação ampliaram as demandas do mercado de trabalho, que passou a exigir profissionais mais bem qualificados para atuar nas empresas e atingir os níveis de produtividade. Atualmente, os profissionais, de modo geral, devem saber utilizar com eficiência as tecnologias da informação, sendo capazes de gerenciálas de forma efetiva e pertinente. Assim, é preciso que os profissionais tenham habilidades e conhecimentos para processar e utilizar as informações, que se multiplicam e se tornam cada vez mais complexas. Esse processo aliado às políticas educacionais no Brasil demandou uma elevação do nível de formação profissional, que passou a ser de nível superior. Esses cursos 
são realizados em menor período de tempo, possibilitando que o indivíduo adquira as habilidades técnicas para ingressar no mercado de trabalho.

Num primeiro momento, esse processo de formação parece contribuir para a formação integral do cidadão, conciliando o ingresso no mercado de trabalho, o aumento da renda e a formação em nível superior. Mas um olhar mais atento e uma leitura de alguns autores como Brandão (2009), Souza (2012), Schwede e Lima Filho (2015), entre outros citados no presente estudo, permite observar que prevalece no Brasil a formação baseada no modelo capitalista, muito parecida com aquela do período colonial e escravagista.

Vimos que há autores que avaliam os cursos superiores de tecnologia como ofertas de ensino que privilegiam os conhecimentos técnicos, especializados, para que o sujeito ingresse no mercado de trabalho, mas para por aí. Para esses autores, não existe um plano de continuidade dos estudos que leva o sujeito a um processo de formação integral, voltada para a reflexão, para a pesquisa, para o conhecimento científico. Criticam, igualmente, os currículos extremamente técnicos dos cursos superiores de tecnologia que priorizam as demandas do mercado, mas não atendem as necessidades de conhecimento dos indivíduos que buscam uma formação acadêmica em nível superior, o que torna a qualidade dos cursos superiores de tecnologia assunto de debates e controvérsias.

No entanto, essa é uma generalização que não contempla propostas acadêmicas opostas, que enfatizam a formação ética, político-crítica e transformadora. Há uma evolução, nesse sentido, nos cursos tecnológicos, sobretudo na pós-graduação.

Em resposta ao problema de pesquisa apresentado na introdução deste estudo (é possível melhorar a qualidade acadêmica dos cursos superiores de tecnologia?), concluímos que a melhoria da qualidade acadêmica dos cursos superiores passa pela inserção de conteúdos científicos voltados para a reflexão e pesquisa, pela formação geral e pela formação de professores para atuar no ensino profissionalizante de nível superior.

Em relação à formação de professores, constatamos que os programas de formação específica para atuar em cursos superiores de tecnologia começam a se concretizar, mas ainda não são suficientes. Por serem cursos basicamente técnicos, muitos professores que lecionam nesses cursos não possuem formação pedagógica. Pelo contrário, eles são profissionais (técnicos/especialistas) que atuam no mercado de trabalho e são contratados pelas instituições de ensino superior para lecionar a disciplina na qual é especializado. Em busca de solução para esta limitação, os mestrados profissionais estão ocupando este espaço.

Identificamos que existe a carência de profissionais com formação acadêmica na área de educação para atuar nos cursos superiores de tecnologia. Assim, os professores 
especialistas que atuam nos cursos superiores de tecnologia devem privilegiar a continuidade de sua formação, nas disciplinas da educação, para que possam oferecer uma formação integral, voltada para a reflexão e cidadania, baseada nos debates científicos e não apenas uma formação de caráter técnico.

Para trabalhos futuros, sugerimos que seja realizada uma pesquisa com algumas empresas para identificar se os profissionais formados nos cursos superiores de tecnologia atendem as demandas do mercado de trabalho, as demandas sociais, e também com os alunos desses cursos, para que eles relatem suas experiências, expectativas e críticas.

A proposta de cursos de tecnologia vigentes pode contribuir de modo significativo para que os indivíduos tenham uma formação em nível superior na área específica e profissional voltada a uma profissionalização, apesar de, historicamente, terem se desenvolvidos para o mercado, fomentados pelos grandes financiadores mundiais. Mas, partindo da importância dessa formação profissional, observamos que muitas instituições de ensino tecnológico buscam superar o dilema entre servir o mercado e atender o desenvolvimento profissional que o trabalho tecnológico carece, tendo como pano de fundo a busca da compreensão e da crítica sobre a educação historicamente reservada à classe trabalhadora.

A oposição à lógica das competências, voltada apenas para o mercado de trabalho, fragmentando o conhecimento, oferecendo uma perspectiva interdisciplinar e crítica, pode ser uma perspectiva que se vislumbra.

A melhoria da qualidade dos cursos superiores de tecnologia passa, sobretudo, na superação da tradição brasileira em formar mão de obra para o mercado de trabalho. Como o mercado de trabalho tem exigido mão de obra mais qualificada e especializada, o nível da formação profissional tecnológica alcançou o nível superior. Porém, esses cursos ainda são estigmatizados, sendo considerados de qualidade inferior, o que não pode ser uma generalização, pois cursos de outras naturezas também apresentam limitações e não oferecem a desejável criticidade.

Mas é importante afirmar que os CSTs possibilitam que os indivíduos tenham uma formação em nível superior e possam dar continuidade a seus estudos, atingindo níveis acadêmicos mais elevados. Além disso, a formação em um curso superior de tecnologia pode contribuir para a entrada no mercado de trabalho, com uma renda baseada em uma formação para este nível.

Por fim, concluímos que deve haver maior investimento por parte das políticas públicas na educação básica e de ensino médio, para que essa qualidade passe a ser refletida 
no ensino superior. O curso superior de tecnologia deve ser considerado como primeiro passo para que o indivíduo atinja uma formação de nível superior. Mas ele não deve parar por aí, deve continuar investindo em sua formação, que deve ir além das demandas do mercado de trabalho.

A educação tecnológica deve proporcionar ao aluno uma formação integral. Entendemos que ela objetiva formar um sujeito capaz de lidar com a tecnologia e a ciência atuais, envolvendo aprendizado e reflexão sobre suas aplicações, fundamentos e desenvolvimento. Além disso, a educação tecnológica também deve preocupar-se com a formação integral do cidadão, gerando nele uma capacidade de tomada de decisões, uso de raciocínio crítico frente às questões políticas, humanas e sociais do mundo em que está inserido.

AGRADECIMENTOS: Aos integrantes do Núcleo de Estudos sobre o Professor, a Arte e a Filosofia - NEPAFi e à Rede de Pesquisadores sobre o Professor no Centro-Oeste REDECENTRO.

\section{REFERENCIAS}

ALVES, L. A. M. História da Educação uma introdução. Porto/Portugal: Faculdade de Letras da Universidade do Porto. Biblioteca digital, 2012.

APPOLINÁRIO, F. Dicionário de metodologia científica: um guia para a produção do conhecimento científico. São Paulo: Editora Atlas, 2004.

ARAUJO, A. B. Educação tecnológica para a indústria brasileira. Revista Brasileira da Educação Profissional e Tecnológica, Natal, v. 1, n. 1, jun. 2008. Disponível em: http://portal.mec.gov.br/setec/arquivos/pdf3/rev_brasileira.pdf. Acesso em 20 jan. 2016.

AZEVEDO, A. J. A influência da pedagogia tecnicista na prática docente de uma escola de educação básica. Revista Científica Eletrônica de Pedagogia, ano XI, n. 21, jan. 2013. Disponível em: www.revista.inf.br. Acesso em: 23 maio 2015.

AZEVEDO, J. C. Globalização, tecnicismo e os desafios para uma educação comprometida com a formação humana. Rizoma freireano, v. 10, jul./dez. 2011. Disponível em: http://www.rizoma-freireano.org/index.php/globalizacao-tecnicismo-e-os-desafios-para-umaeducacao-comprometida-com-a-formacao-humana-jose-clovis-de-azevedo. Acesso em: 02 jul. 2015.

AZEVEDO, L. A. de. De CEFET a IFET. Cursos superiores de tecnologia no Centro Federal de Educação Tecnológica de Santa Catarina: gênese de uma nova institucionalidade? 2011, 383 f. Tese (Doutorado em Educação) - Centro de Ciências da Educação. Programa de Pós-Graduação em Educação, Universidade Federal de Santa Catarina. Florianópolis, SC, 2011. 
BACCEGA, M. A. Conhecimento, informação e conhecimento. Comunicação \& Educação, São Paulo, 111:7-16, jan./abr. 1998. Disponível em:

http://revistas.univerciencia.org/index.php/comeduc/article/view/4062/3814. Acesso em: 25 abr. 2015.

BARROS, L.; SOUSA, J. A. Fundamentos, Características y Perspectivas de la Educación Tecnológica. Boletin Cinterfor, n. 141, p. 7-28, out./ dez. 1997.

BEATRICI, R. F. A educação como cultura. REP - Revista Espaço Pedagógico, Passo Fundo, v. 16, n. 2, p. 171-175, jul./dez. 2009.

BRANDÃO, M. Cursos superiores de tecnologia: democratização do acesso ao ensino superior? In: REUNIÃO ANUAL DA ANPED, 29, 2009. Anais... Caxambu: ANPEd, 2009. Disponível em: - Int.pdf. Acesso em: set. 2016.

\section{BRASIL. Constituição (1988). Constituição da República Federativa do Brasil.}

\section{BRASIL. Lei de Diretrizes e Bases da Educação - LDB 9.394/1996}

BRASIL. Conselho Nacional de Educação. Resolução CNE/CP 1/2002.Institui as diretrizes curriculares nacionais para a formação de professores da educação básica, em nível superior, curso de licenciatura, de graduação plena. Brasília, DF, 2002a.

BRASIL. Resolução CNE/CP n⿳ 3/2002. Institui as Diretrizes Curriculares Nacionais Gerais para a organização e o funcionamento dos Cursos Superiores de Tecnologia. Brasília, DF, 2002. Disponível em:

http://portal.mec.gov.br/setec/arquivos/pdf_legislacao/rede/legisla_rede_resol03.pdf>. Acesso: 23 nov. 2016.

BRASIL. Decreto ${ }^{\circ} 5.154$, de 23 de julho de 2004. Regulamenta o $§ 2^{\circ}$ do art. 36 e os arts. 39 a 41 da Lei $n^{\circ}$ 9.394, de 20 de dezembro de 1996, que estabelece as diretrizes e bases da educação nacional, e dá outras providências. Diário Oficial da União, Brasília, DF, 24 jul. 2004. Disponível em: http://www.planalto.gov.br/ccivil_03/_ato2004-

2006/2004/decreto/d5154.htm. Acesso em: 30 abr.2017.

BRASIL. Resolução CNE/CEB no 1/2005. Atualiza as Diretrizes Curriculares Nacionais definidas pelo Conselho Nacional de Educação para o Ensino Médio e para a Educação Profissional Técnica de nível médio às disposições do Decreto no 5.154/2004. Disponível em: https://www.legisweb.com.br/legisweb_novo/legislacao/?id=103150. Acesso em: $30 \mathrm{abr}$. 2017.

BRASIL. Ministério da Educação e Cultura. Catálogo Nacional de Cursos Superiores de Tecnologia. Brasília, DF, 2006.

BRASIL. Expansão da Rede Federal de Educação Profissional, Científica e Tecnológica. 2014b. Disponível em:

BRASIL. Políticas públicas para a educação profissional e tecnológica. Brasília, DF, 2004. BRASIL. Plano Nacional da Educação. Brasília, DF, 2014. 
BRASIL. Presidência da República. Casa Civil. Subchefia para Assuntos Jurídicos. Lei no 13.005, de 25 de junho de 2014. Plano Nacional de Educação-PNE - 2014-2014. Disponível em: http://www.planalto.gov.br/CCIVIL_03/_Ato2011-2014/2014/Lei/L13005.htm. Acesso em: 3 dez. 2016.

CÂMARA, C. A. Docência no ensino superior: um desafio para a formação? Revista Científica Eletrônica de Ciências Sociais Aplicadas da Eduvale: publicação científica da Faculdade de Ciências Sociais Aplicadas do Vale de São Lourenço, Jaciara, ano 3, n. 5, out. 2010.

CASTELLS, M. A. Sociedade em Rede. 11. ed. São Paulo: Editora Paz e Terra, 2008. vol. 1.

CELLARD, A. A análise documental. In: POUPART, Jean et al. A pesquisa qualitativa: enfoques epistemológicos e metodológicos. Petrópolis: Vozes, 2008 (Coleção Sociologia).

\section{CENTRO ESTADUAL DE EDUCAÇÃO TECNOLÓGICA PAULA SOUZA. Perfil e} histórico. São Paulo, 2015. Disponível em: < http://www.centropaulasouza.sp.gov.br/quemsomos/perfil-historico/>. Acesso em: jul.2015.

COELHO, S. L. B. Repensando um Projeto de Educação Tecnológica Referenciado na Formação do cidadão-técnico: algumas reflexões para a formulação de novas propostas educativas. Educação \& Tecnologia, Belo Horizonte, n. 2, p. 52-56, jul./dez. 1997.

COLOMBO, C.R.; BAZZO, W.A. Educação tecnológica contextualizada, ferramenta essencial para o desenvolvimento social brasileiro. Biblioteca Digital da OEI. 2002. Disponível em: . Acesso em: abr. 2015.

\section{CONSELHO DE DIRIGENTES DOS CENTROS FEDERAIS DE EDUCAÇÃO} TECNOLÓGICA. Manifestação do CONCEFET sobre os Institutos Federais de Educação, Ciência e Tecnologia. 2007. Disponível em: www.celia.na web.net/pasta8/CONCEFET_Manifestacao_IFET.pdf. Acesso em: jun. 2015.

COSTA, E.; FARIAS, E. Formação de professores profissionais: perspectivas e vicissitudes na formação em serviço. 2008. Disponível em:

http://www.infoeducativa.com.br/index.asp?page=artigo\&id=20. Acesso em: abr. 2016.

CUNHA, L. A. O ensino industrial-manufatureiro no Brasil. Revista Brasileira de Educação, n. 14, p. 89-107, 2000. Disponível em: http://189.1.169.50/rbe/rbedigital/RBDE14/RBDE14_07_LUIZ_ANTONIO_CUNHA.pdf. Acesso em: 09 set. 2016.

DONATO, A. Em torno de algumas questões educacionais. Oboré Projetos Especiais em Comunicações e Artes. Disponível em: http://www.obore.com.br/artigosIntegra.asp?cd=49. Acesso em: jul. 2015.

DRUCKER, P. F. On the profession of Management. Cambridge, Mass.: Harvard Business School Press, 2001.

DUCH, M. A. B. G.; LAUDARES, J. B. Estudo da implementação de cursos superiores de Tecnologia por instituições de ensino superior mineiras. Trabalho \& Educação, v.18, n.1, p. 
133-154, jan./abr.2009. Disponível em:

https://seer.ufmg.br/index.php/trabedu/article/view/7031. Acesso: 29 abr. 2017.

FELIZARDO, J. M. Capitalismo, organização do trabalho e tecnologia da produção e seus impactos na qualificação da força de trabalho. 2010. Revista Labor, n. 3, v. 1, 2010.

FERRARI, M.E.F. O momento atual é interessante porque põe a escola em crise. Nova Escola. São Paulo, 2014. Disponível em: http://revistaescola.abril.com.br/linguaportuguesa/alfabetizacao-inicial/momento-atual-423395.shtml. Acesso em: abr. 2015.

FERREIRA, C. M. L. A educação tecnológica no terceiro milênio: implicações do pensamento complexo de Edgar Morin. 2013. Tese (Doutorado em Educação) - Faculdade de Educação, Universidade de São Paulo, São Paulo, 2013.

FERRETTI, C. J. Formação profissional e reforma do ensino técnico no Brasil: anos 90. Educação \& Sociedade, ano XVIII, n ${ }^{\circ}$ 9, agosto/1997. Disponível em: http://www.scielo.br/pdf/es/v18n59/18n59a01.pdf. Acesso em: jun. 2015.

FONSECA, C. S. História do ensino industrial no Brasil. Rio de Janeiro: Escola Técnica, 1961.

FREIRE, P. Educação e mudança. 12. ed. São Paulo: Paz e Terra, 1979. Disponível em: http://www.hdbr.org.br/data/site/uploads/arquivos/Paulo\%20Freire\%20$\% 20$ Educa\%C3\%A7\%C3\%A3o\%20e\%20Mudan\%C3\%A7a.pdf. Acesso em: mai. 2015.

FREIRE, P. Pedagogia do oprimido. Rio de Janeiro, RJ: Paz e Terra. 1970.

FRIGOTTO, G. Globalização e crise do emprego: mistificações e perspectivas da formação técnico-profissional. Boletim SENAC, v. 2, n. 25, 1999. Disponível em: http://www.senac.br/INFORMATIVO/BTS/252/boltec252c.htm. Acesso em: 11 out. 2010.

FRIGOTTO, G. Relação da educação profisssional e tecnológica com a universalização da educação básica. In: CONFERÊNCIA NACIONAL DE EDUCAÇÃO PROFISSIONAL E TECNOLÓGICA, 1, 2016, Brasília. Anais... Disponível em:

http://portal.mec.gov.br/setec/arquivos/pdf/conferencia_curriculo_frigoto.pdf. Acesso em: set. 2016.

GADOTTI, M. Trabalho e educação numa perspectiva emancipatória. In: Fórum mundial de educação profissional e tecnológica, 2., 2012, Florianópolis. Disponível em: . Acesso em: abr. 2015.

GARCÍA, M. I. G. Ciencia, Tecnologia y Sociedad: una introducción al estudio social de la ciencia y la tecnología. Madrid: Tecnos, 2000.

GENTILE, P. B. T. Precisamos de cidadãos do mundo. Nova Escola, São Paulo, ed. 149, 2002. Disponível em: http://revistaescola.abril.com.br/formacao/precisamos-cidadaos-mundo425252.shtml. Acesso em: abr. 2015.

GOULART, J.; GERBELLI, L. G.; PEREIRA, R. 20 anos de Plano Real: sete reflexões sobre a estabilização. Estadão, São Paulo, 30 jun. 2014. Economia. Disponível em: . Acesso em: maio 2016. 
GUZMÁN, J. Y. Las TIC y la crisis de la educación: algunas claves para su comprensión. 2016. Disponível em: http://virtualeduca.org/documentos/yanez.pdf. Acesso em: 10 set. 2016.

GRINSPUN, M. P. S. Z. A prática dos orientadores educacionais.4. ed. São Paulo: Cortez, 2001

HEIDEGGER, M. Serenidade. Tradução: Maria Madalena Andrade e Olga Santos. Título Original: Gellassnheit. Editora. Piaget, 1969.

HOBSBAWM, E. Era dos extremos - o breve século XX. Ed. Companhia das letras. 1995.

JUCÁ, M. C.; OLIVEIRA, P. J.; SOUZA, R. J. Cursos Superiores Tecnológicos: um avanço da educação superior no Brasil. In: Colóquio internacional sobre gestion universitária em America del Sur, X. Argentina, 2010. Disponível em:

https://repositorio.ufsc.br/xmlui/bitstream/handle/123456789/97065/CURSOS\%20SUPERIO RES\%20TECNOL\%C3\%93GICOS\%20UM\%20AVAN\%C3\%870\%20DA\%20EDUCA\%C3 $\% 87 \%$ C3\%83O\%20SUPERIO.pdf?sequence=1\&isAllowed=y. Acesso em: 10 out. 2015.

KUENZER, A. Z. Ensino médio e profissional: as políticas do Estado neoliberal. São Paulo: Cortez, 1997. (Questões da nossa época; v. 63). p. 12.

LIMA, T. C. S.; MIOTO, R. C. T. Procedimentos metodológicos na construção do conhecimento científico: a pesquisa bibliográfica. Revista Katalysis, v. 10, p. 35-45, 2007.

LIMA, F. B. G.; SILVA, K. A. C. P. C. A Consolidação dos Institutos Federais de Educação, Ciência e Tecnologia: um estudo da concepção política. In: $36^{\circ}$ Reunião Nacional da ANPEd, 2013. Anais...Goiânia, GO: ANPEd, 2013. Disponível em:

http://36reuniao.anped.org.br/pdfs_trabalhos_aprovados/gt09_trabalhos_pdfs/gt09_2637_text o.pdf. Acesso em: 25 abril 2016.

LOPES, K. R.; MENDES, R.P.; FARIA, V.L.B. (orgs.). Livro de estudo. Brasília: MEC. SEB.SEAD. 36p. (Coleção PROINFANTIL; Unidade 2). 2005.

LOPES, M. R. C. Currículo prescritivo e disciplinador do estado de São Paulo (20082010): Geografia no Ensino Médio. Dissertação (Mestrado em Educação), Faculdade de Educação, Pontifícia Universidade Católica de São Paulo, São Paulo, 2014. Disponível em: https://sapientia.pucsp.br/bitstream/handle/10456/1/Maria\%20Rita\%20de\%20Castro\%20Lope s.pdf. Acesso em: 10 abr. 2016.

LUCKESI, C. C. Filosofia da educação. São Paulo: Cortez, 2003.

MACHADO, L. R. S. Diferenciais inovadores na formação de professores para a educação profisssional. Revista Brasileira da Educação Profissional e Tecnológica, v. 1, n. 1, jun. 2008. Disponível em: . Acesso em: 15 maio 2015.

MARQUES, A. A. A pedagogia tecnicista: um breve panorama. Revista Eletrônica do Curso de Pedagogia do Campus Jataí UFG, v. 1, nº 12, 2012.

MASETTO, M. T. Docência na universidade. 9. ed. Campinas, SP: Papirus, 2008. 
MÉDICI, A. Welfare State no Brasil. Curso de Formação de Formadores para Gestão de Políticas Públicas no Sistema Público de Emprego e Renda. 11 maio 2006. Disponível em: . Acesso em: 15 abr. 2016.

MELLO, M. B. J. B. Motivação de alunos dos cursos superiores de tecnologia. 2015. Dissertação (Mestrado em Psicologia) - Faculdade de Psicologia, Universidade de São Paulo, São Paulo. Disponível em: http://www.teses.usp.br/teses/disponiveis/47/47131/tde-05082015124851/pt-br.php. Acesso em: 15 abr. 2016.

MORIN, E. A cabeça bem-feita: repensar a reforma, reformar o pensamento; tradução Eloá Jacobina, 8. ed. Rio de Janeiro: Bertrand Brasil, 2015.

O MANIFESTO DOS PIONEIROS DA EDUCAÇÃO NOVA (1932). A reconstrução educacional no Brasil - ao povo e ao governo. Revista HISTEDBR On-line, Campinas, SP, n. especial, p.188-204, ago. 2006.

MOURA, D. H. A formação de docentes para a educação profissional e tecnológica. Revista Brasileira de Educação Profissional e Tecnológica. 2016. Disponível em:

http://www2.ifrn.edu.br/ojs/index.php/RBEPT/article/viewFile/2863/1004. Acesso em: 10 set. 2016.

NOSELLA, P.; AZEVEDO, M. L. N. A educação em Gramsci. Rev. Teoria e Prática da Educação, v. 15, n. 2, p. 25-33, mai./ago. 2012.

NUNES, T. S. F. Implicações da política de educação superior de tecnologia na constituição da docência nos cursos de graduação de tecnólogos. 2011, 298fl. Tese (Doutorado em Educação) - Universidade Federal de Pernambuco, CE, Programa de Pósgraduação em Educação. Recife, PE, 2011. Disponível em: . Acesso em: 15 abr. 2016.

NUNES DURÃES, M. Educação Técnica e Educação Tecnológica: múltiplos significados no contexto da educação profissional. Educação \& Realidade. vol. 34, n. 33, set./dez. 2009. Disponível em: http://seer.ufrgs.br/index.php/educacaoerealidade/article/view/9365/6716. Acesso em: 5 dez. 2016.

ORGANIZAÇÃO DOS ESTADOS IBERO-AMERICANOS. Sistema Educativo Nacional de Brasil. 2010. Disponível em: http://www.oei.es/quipu/brasil/contexto.pdf. Acesso em: 20 maio 2016.

OLIVEIRA, J. F. A. C.; CARNEIRO, M. E. F. As políticas neoliberais para a educação profissional: analisando o governo Fernando Henrique Cardoso e Luís Inácio Lula da Silva. Disponível em: . Acesso em: 30 abr. 2017.

OLIVEIRA, M. R. N. S. Mudanças no mundo do trabalho: acertos e desacertos na proposta curricular para o ensino médio (Resolução CNE 03/98): diferenças entre formação técnica e formação tecnológica. Educação e Sociedade, Campinas, n. 70, p. 40-62, abr. 2000.

OLIVEIRA, M. M. Como fazer pesquisa qualitativa. Petrópolis: Vozes, 2011.

OLIVEIRA. S. Cursos superiores de tecnologia: concepções de tecnologia e perfis profissionais de conclusão. 2011. 158 f. Dissertação (Mestrado em Educação) - Programa de Pós-Graduação em Educação, Universidade do Estado de Santa Catarina, Florianópolis, 2011. 
Disponível em: http://www.faed.udesc.br/arquivos/id_submenu/151/sandro_de_oliveira.pdf. Acesso em: 07 abr. 2016.

PACHECO, E. Os institutos federais. Brasília: Moderna, 2011.

PAIR, C. A. Formação profissional, ontem, hoje e amanhã. In: DELORS, Jacques (Org.). A Educação para o século XXI: questões e perspectivas. Porto Alegre: Artmed, 2005. p. 172186.

PETEROSSI, H. G. Educação e mercado de trabalho: análise crítica dos cursos de tecnologia. São Paulo: Edições Loyola, 1980.

PIMENTA, S. G.; ANASTASIOU, L. G. C. Docência no ensino superior. São Paulo: Cortez, 2002. v. 1.

PIMENTEL, A. O método da análise documental: seu uso numa pesquisa historiográfica. Cadernos de Pesquisa, n.114, p.179-195, nov. 2001.

PRAXEDES, L.A. A formação para o trabalho em cursos superiores de tecnologia: uma análise a partir da perspectiva da ontologia do ser social marxiana. Dissertação (Mestrado em Educação) - Faculdade de Educação, Universidade Federal de Minas Gerais, Belo horizonte, 2014.

RAJASEKAR, S.; PHILOMINATHAN, P.; CHINNATHAMBI, V. Research methodology. Physics. 2013. Disponível em: http://arxiv.org/pdf/physics/0601009.pdf. Acesso em: 20 jun. 2016.

RAMOS, J. M. R. Dimensões da globalização: comunicações, economia, política e ética. Revista de Economia \& Relações Internacionais, vol. 1 (21), n. 1, jul. 2002.

RECHIA, K. C.; SCHMIDT, L. L.; SCHARDONG, R. História da Educação I. Disciplina na modalidade a distância. Palhoça, RS: UnisulVirtual, 2006.

REIS, M. F. Educação Tecnológica: a montanha pariu um rato? Portugal: Porto Editora, 1995.

ROCHA, M. B. Cursos superiores de tecnologia: indicações de como se expande a educação superior no Brasil. In: REUNIÃO ANUAL ANPED, 35, 2012, Anais... Porto de Galinhas: ANPEd, 2012. Disponível em: http://35reuniao.anped.org.br/images/stories/trabalhos/GT09\%20Trabalhos/GT091900_int.pdf. Acesso em: 12 abr. 2016.

ROSETTI JÚNIOR, H.; SANTIAGO, R. A.; SCHIMIGUEL, J. Estudo curricular de cursos superiores de tecnologia e matemática financeira. HOLOS, ano 29, v. 2, p. 216-227, 2013.

SANTAGADA, S. Indicadores sociais: uma primeira abordagem social e histórica.

Pensamento Plural, Pelotas, n. 01, p.113-142, jul/dez/2007.

SANTOS, D. Graduação tecnológica no Brasil: crítica a expansão de vagas no ensino superior não universitário. 2009. Tese (Doutorado) Programa de Pós-graduação em Educação 
Brasileira, Faculdade de Educação - FACED, Universidade Federal do Ceará, Fortaleza, 2009.

SANTOS, D. G.; JIMÉNEZ, S. V. Graduação Tecnológica no Brasil: aproximações críticas preliminares. Linhas Críticas, Brasília, v. 15, n. 28, p. 171-185, jan./jun. 2009.

SANTOS, F. M. Significações de construtivismo na perspectiva de professores construtivistas e sua relação com práticas avaliativas. 2007. Dissertação (Mestrado em Educação) - Programa de Pós-graduação em Educação, Faculdade de Educação, Universidade Católica de Brasília, Brasília, 2007. Disponível em: . Acesso em: 15 abr. 2016.

SANTOS, M. H. Construindo a competência. São Paulo: Olho d’Água, 2004.

SANTOS, N. F. A formação inicial de professores de física em centros federais de educação tecnológica: contribuições e críticas. Rio de Janeiro. RJ. 2004. Dissertação (Mestrado em Educação) - Centro de Educação e Humanidades, Universidade do Estado do Rio de Janeiro, 2004. Disponível em: http://www.curriculouerj.pro.br/imagens/pdfteses/a_formacao_44.pdf. Acesso em: 5 abr. 2016.

SAVIANI, D. Trabalho e educação: fundamentos ontológicos e históricos. Revista Brasileira de Educação, v. 12, n. 34 jan./abr. 2007. Faculdade de Educação, Universidade Estadual de Campinas, 2007.

SCHON, D. Educating the reflective practioner. São Francisco, CA: Jossey-Bass, 1987.

SCHUMPETER, J. A. Os Economistas. São Paulo: Abril Cultural, 2012.

SCHWARTZMAN, S. Por uma nova política de educação superior para o Brasil. 2007. Disponível em: < http://www.schwartzman.org.br/simon/poledsup.pdf> Acesso em: 3 mai. 2016.

SCHWEDE, M. A.; FILHO, D. L. L. Os Institutos Federais de Educação, Ciência e Tecnologia: dos motivos para a sua constituição á produção da ciência e da tecnologia. In: $37^{\circ}$ Reunião Nacional da ANPEd, out. 2015, Florianópolis.

SHIROMA, E. O.; MORAES, M. C. M.; EVANGELISTA, O. Política educacional. 4. ed. Rio de Janeiro: Lamparina, 2007.

SILVA, D. A. O papel do professor no processo ensino- aprendizagem face das contínuas e rápidas mudanças advindas no decorrer do séc. XXI. 2008. Disponível em:

http://www.artigonal.com/ensino-superior-artigos/o -papel-do-professor-no- processo-enisnoaprendizagem-face-das-continuas-e-rapidas-mudanças- advindas-no-decorrer-do-sec-xxi385590.html. Acesso em: 7 abr. 2016.

SIMÕES, D. D. R. Ensino técnico: desde o período colonial à era neoliberal. Seminário nacional de estudos e pesquisas "história, sociedade e educação no Brasil", História, educação e transformação: tendências e perspectivas, VIII, 2009. Anais... Universidade Estadual de Campinas - UNICAMP, 2009. 
SOUSA JUNIOR, J. Trabalho e Educação: diálogos necessários. In: Reunião nacional da ANPED, 37, 2015. Anais... Florianópolis: ANPEd, 2015.

SOUZA, J. B. Política de expansão dos Cursos Superiores de Tecnologia: nova face da educação profissional e tecnológica. 2012. Tese - (Doutorado em Educação) - Faculdade de Educação, Universidade Federal de Minas Gerais, Belo Horizonte, 2012. Disponível em: . Acesso em: 15 abr. 2016.

TAKAHASHI, A.R.W. Cursos superiores de tecnologia em gestão: reflexões e implicações da expansão de uma (nova) modalidade de ensino superior em Administração no Brasil. Revista de Administração Pública, Rio de Janeiro, v. 44, n. 2, mar./abr. 2010.

TIGRE, P. B. Gestão da inovação. Rio de Janeiro: Campus, 2006.

TOIVONEN, M.; TUOMINEN, T. Emergence of innovations in services. Service Industries Journal, v. 29, n. 7, p. 887-902, 2009.

TORRES, M. Aula universitária e inovação. In: TORRES, M. Pedagogia universitária: a aula em foco. Campinas: Papirus, 2006. p. 30-45.

VAN DE VEN, A; POLLEY, D.; GARUD, R.; VENKATARAMAN, S. The innovation journey. New York: Oxford University Press, 2009.

VERASZTO, E. V. Tecnologia: buscando uma definição para o conceito. Prisma.com, n.07, 2008.

VIDAL, D. G.; FARIA FILHO, L. M. História da educação no Brasil: a constituição histórica do campo (1880-1970). Revista Brasileira de História. São Paulo, v. 23, n. 45, pp. 37-70, jul. 2003.

ZARTH, P. A. et. al. Os caminhos da exclusão social. Ijuí: Editora Unijuí, 1998.

ZIBAS, D. M. L. Uma visão geral do ensino técnico no Brasil. [Texto apresentado no:

Encuentro Internacional sobre Educación Técnico-Profesional, financiado pelo BID - Banco Interamericano de Desenvolvimento e organizado pelo BID e pelo Ministerio de Educación, Ciencia y Tecnología de la Nación Argentina Buenos Aires, em 6 e 7 de dezembro de 2006]. Fundação Carlos Chagas, p. 4, jan. 2007. Disponível em: /uma-visao-geral-do-ensino-tecnicono-brasil-fundaao-carlos-chagas_59f378691723dda6db89816f.html. Acesso em: 20 out. 2016.

ZYCH, A. C.; VASSÃO, A. M. A importância do estágio curricular na formação do profissional crítico. Congresso nacional de educação, XIII; Seminário de representações sociais, subjetividade e educação, II; Seminário internacional sobre profissionalização docente, IV, 2013. Anais... Curitiba, 2013. Disponível em: Acesso em: 20 out. 2016.

\section{Como referenciar este artigo}


CAZAROTTI, M. L. B.; BERNARDES, S. T. de A. Cursos superiores de tecnologia: fundamentos, controvérsias \& desafios. Revista on line de Política e Gestão Educacional, Araraquara, v. 22, n. 3, p. 992-1046, set./dez. 2018. E-ISSN:1519-9029. DOI: 10.22633/rpge.v22i3.11368

Submetido em: $27 / 04 / 2018$

Aprovado em: 28/06/2018 